\title{
Hybrid Anglo-Japanese loans in Korean
}

NICOLAS TRANTER

Abstract

The paper discusses, categorizes, and explains the phenomenon of "hybrid" loans in Korean, whereby a loan-word reflects the phonology/morphology of not one but two languages simultaneously. One well-known form of hybrid loan is that of the great number of Sino-Japanese neologisms that, through Korea and Japan's shared use of Chinese characters, have been copied orthographically but not phonetically into Korean. In addition, many of the large numbers of English words that have entered Korean display phonological or morphological influence from Japanese in some respects but are nevertheless hybrid loans in that, although some features can only be accounted for through borrowing from Japanese, other features of the same words can only be accounted for through direct borrowing from English.

\section{Introduction}

Substantial loans over a short period of time generally follow strict principles of sound correspondence, for which rules or principles of the same type as are applied to sound changes within a language over time may be posited. Japanese, which has substantially borrowed from English during the last 50 years, has been particularly well studied in this regard, and numerous academic studies and reports regarding the regularity of the English-Japanese loan process have emerged (such as Lovins 1975; Quackenbush 1977; Kokuritsu Kokugo Kenkyūjo 1990). In Korea, also, substantial borrowing from English has occurred. Loan-words (oeraeŏ) constitute at least $5 \%$ of the vocabulary of Korean and are constantly increasing in number. Up to $90 \%$ of such loan-words are from English and the vast majority have been introduced over the last half-century, with Japanese as the second major source (Sohn 1994: 528-529). 
However, whereas the academic approach toward loan-words in Japan has tended to be more descriptive, a strongly prescriptive approach has characterized Korean treatments of loan-words, which typically list the "correct" spelling and form of loan-words (such as Pak 1988). A noteworthy feature of such lists has been the replacement of irregular copies of English words, particularly those that have entered the language in a Japanified form, with more regular forms. Many such replacements have entered the everyday spoken language, often with the result that older and newer forms coexist. However, although some older forms have been made obsolete by newer forms, others continue to persist, and occasionally even prescriptive works fail to correct certain irregularities.

The statistics quoted above hide the substantial influence that the Japanese language has had on the Korean language over the last century. First, a not-insignificant proportion of the modern vocabulary of Korean is built from Chinese roots but was in fact created in Japan. Nevertheless, those Chinese words borrowed directly from Chinese and those Chinesebased words invented in Japan are all subsumed under the general term hanjaŏ 'Chinese character words', usually translated into English as 'SinoKorean', and are treated separately from the oeraeo component of the vocabulary. Second, many of the English loan-words in Korean have entered the language not directly from English but through a Japanese intermediary form, giving rise to strangely hybrid forms of which some features reflect Japanese phonology and others reflect English phonology. ${ }^{1}$ Other hybrid loans now completely conform to the regular sound correspondences that govern direct loans from English, yet in certain features of word formation are Japanese, as the equivalent form does not exist in English.

The discussion below deals initially with overt Japanese loans into Korean and Japanese-coined Sino-Korean (section 2) and then, after dealing with direct English loans into Korean, the sound correspondence rules involved, and the social motivation for such loans (section 3), considers various features of hybrid Anglo-Japanese loans in Korean (section 4) and some of the consequences of linguistic purification (section 5).

\section{Japanese loans in Korean}

Until 1894, Korea was essentially a satellite of China and the Korean government was dominated by pro-Chinese conservatives. Society was structured along Neo-Confucian principles and the official written language of the country was Chinese. A reformist movement, however, was 
led by young intellectuals who had studied in Japan and who looked to Japan as a model of a successfully modernizing Asian country (Tanaka and Lee 1986: 124). In 1894, the reformists achieved dominance and instigated reforms. Chinese dominance was thrown off, and official legislation rapidly replaced the Chinese language with Korean as the national language and heavily promoted the use of hangül, the native Korean script (Hannas 1994: 146-147).

Unlike the situation in China and Korea, a modernizing faction had achieved dominance in Japan a quarter of a century earlier (Mackerras 1992: 169-172), and modernization of Japan had been accompanied by the modernization of the language at least at the lexical level. ${ }^{2}$ Large numbers of technical terms had been coined in Japan from Chinesederived roots - Sino-Japanese lexemes, or kango - in order to express new political, economic, philosophical, medical, and military concepts from the West. As a result, the pro-Japanese reformers within Korea began modernizing their language, and as the Japanese and Korean languages shared the vast stock of Chinese morphemes, most of these Japanese neologisms were taken directly into Korean - as Sino-Korean lexemes or hanjao. The influence of Japanese grew with the annexation of Korea by Japan in 1910, from which time the Japanese language acquired a dominant role in government (Tanaka and Lee 1986: 126), and great numbers of Sino-Japanese terms became Sino-Korean terms through Japanese dominance. Although most of the loans from Japanese were built from Chinese elements, increasing numbers of native Japanese words and some established Western loan-words in Japanese were borrowed into Korean.

Although Korean has been gradually purged of a great number of Japanese words during a number of language-purification campaigns since the liberation in 1945 (Tanaka and Lee 1986: 128; Hannas 1994: 149), many Japanese words, especially those that express aspects of Japanese culture such as the cuisine, are still in everyday use. Indeed, other Japanese words have entered Korean in more recent years accompanying new popular concepts, such as karaoke. Among Japanese words that still exist in Korean are the following:

\begin{tabular}{|c|c|c|}
\hline Korean & Japanese & \\
\hline kaban & kaban & 'bag' \\
\hline karaokke & karaoke & 'karaoke' \\
\hline $\begin{array}{l}\text { sŭkkiyakki } \\
\text { teriyakki } \\
\text { udon }\end{array}$ & $\begin{array}{l}\text { sukiyaki } \\
\text { teriyaki } \\
\text { udon }\end{array}$ & $\begin{array}{l}\text { 'sukiyaki' (Japanese food) } \\
\text { 'teriyaki' (Japanese food) } \\
\text { 'wheat noodles' }\end{array}$ \\
\hline
\end{tabular}

In addition, a number of early English loan-words that have entered 
Korean not directly from the original English but through their Japanese forms are still in common usage in their Japanese form. For instance, the expected reflexes for English shirt and bucket in Korean would be as follows: ${ }^{3}$

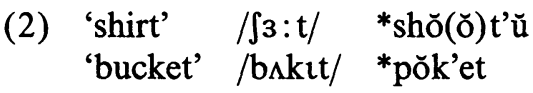

These forms do not occur. The forms that do occur are quite clearly derived from Japanese, which has unusual reflexes for these words because they were borrowed earlier than the vast majority of English loan-words:

$\begin{array}{lll} & \text { Japanese } & \text { Korean } \\ \text { 'shirt' } & \text { shatsu } & \text { shassŭ } \\ \text { 'bucket' } & \text { baketsu } & \text { pakkessŭ }\end{array}$

Here, Japanese $t s u$ is regularly represented in Korean by ssŭ and Japanese $k$ is represented by the ejective $k k$. Since liberation, however, the trend has been to replace Japanese-derived forms with forms derived directly from English. Thus sement'o 'cement', taken straight from the Japanese version semento, has been replaced by a form shiment' $\breve{u}$, derived directly from English (Tanaka and Lee 1986: 127).

The greatest category of overt loans from Japanese consists of the very large number of Sino-Japanese and Sino-Korean words, words in the two languages composed entirely of Chinese-derived morphemes. The following are just a few examples:

(4)

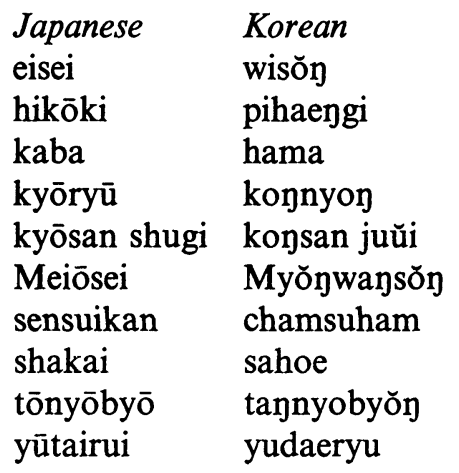

'satellite'
'airplane'
'hippo'
'dinosaur'
'communism'
'(the planet) Pluto'
'submarine'
'society'
'diabetes'
'marsupials'

The cultural dominance of China in the region over the centuries has provided Chinese, Japanese, and Korean with a vast store of morphemes in common that serve as the basis of neoclassical composition in the same way that English and the Romance languages make use of Latin and Greek roots, or the languages of India use Sanskrit roots, to create 
technical terminology (Shibatani 1990: 145-147). ${ }^{4}$ Each of the ten terms above can be broken into two- or three-morpheme compounds. Some, such as 'Pluto' or 'dinosaur', are clearly calques from Western languages:

(5)

$\begin{array}{llll}\text { ka-ba } & \text { 'hippo' } & = & \text { 'river-horse' } \\ \text { kyō-ryū } & \text { 'dinosaur' } & = & \text { 'terror-dragon' } \\ \text { Mei-ō-sei } & \text { 'Pluto' } & = & \text { 'hell-king-star' }\end{array}$

Most are descriptive:

$\begin{array}{llll}\text { ei-sei } & \text { 'satellite' } & =\text { 'guard-star' } \\ \text { hi-kō-ki } & \text { 'airplane' } & = & \text { 'fly-navigate-machine' } \\ \text { kyō-san } & \text { 'communism' } & =\text { 'together-produce' } \\ \text { sen-sui-kan } & \text { 'submarine' } & = & \text { 'dive-water-warship' } \\ \text { sha-kai } & \text { 'society' } & = & \text { 'company-meet' } \\ \text { tō-nyō-byōo } & \text { 'diabetes' } & = & \text { 'sugar-urine-disease' } \\ \text { yū-tai-rui } & \text { 'marsupials' } & = & \text { 'have-bag-class' }\end{array}$

A great many such neologisms have even been incorporated into Chinese such as tángniàobìng 'diabetes', shèhuì 'society', or Míngwángxīng 'Pluto'. The fact that the words are all formed from Chinese elements, and that the Japanese versions involve the loss of certain sounds, such as the $/ \mathrm{y} /$ that occurs in both the Chinese and the Korean versions, would suggest that it is Japan that has borrowed these words from Chinese. The reverse is in fact the case. Over half of the current vocabulary of both Japanese and Korean is derived from Chinese (Shibatani 1990: 142; Sohn 1994: 527), yet a large number of the words, including most of the technical terminology in the spheres of politics, medicine, economics, etc., were not created in China and borrowed by Japan and Korea, but rather were created in Japan from Chinese morphemes, and then borrowed into Korean and back into Chinese. In the second half of the nineteenth century, both China and Korea were still dominated by antireformists who did not recognize the need to modernize so that they could withstand Western (and later Japanese) political and military aspirations. In Japan, on the other hand, the traditional regime was overthrown in 1868 and Japan began developing into a modern industrial nation with Western-style political, economic, and military institutions. Thus, it was Japan that first created new terminology in these important areas.

What Japan has borrowed from Chinese is not the new terms, but rather the individual morphemes that make up the words. Chinese morphemes have been in both languages for over 1500 years, but they have 
diverged greatly from both the original Chinese and the other language over this period. First, such morphemes had to be assimilated to the phonemic systems of the borrowing language. Thus, early Japanese had no sound corresponding to Chinese / $\mathrm{y} /$ and so Middle Chinese way 'king' entered Japanese in the form wau. Second, both the phonemic distinctions and the phonetic realizations of phonemes in both Japanese and Korean have changed greatly over the course of time. Thus, the diphthongs au and $o u$ in Chinese elements in Classical Japanese have over the course of time merged as a long monophthong $\bar{o}$, and $w$ came to be lost before all vowels except $a$. The changes effected wan 'king' regularly in the sequence $w a \eta>w a u>w \bar{o}>\bar{o}$ (Miller 1967: 225-226; Vance 1986: 56).

It might, however, be expected that Japanese kyōry $\bar{u}$ 'dinosaur' would be borrowed by Korean as *kyooryuu or hikōki 'airplane' as *hikkookki, yet the Korean versions konnyon and pihaengi are quite distinct. In fact, these Sino-Japanese compositions were never borrowed by Korean in their spoken form. Rather, they were borrowed only in their written form. Each Chinese morpheme has its own logographic representation, and both the pronunciation and the logograph for each morpheme were borrowed by Japanese and Korean when they were borrowed many centuries before. ${ }^{5}$ Thus, the three characters that are used to write Meiōsei transparently signify 'hell-king-star' in Japanese, Korean, and Chinese, and it is just the combination of logographs that was borrowed into Korean and back into Chinese. Although Middle Chinese wan had changed quite drastically in Japanese into $\bar{o}$, the Korean and Chinese cognates for the morpheme had barely changed, and so Meiōsei reacquired $/ \mathfrak{y} / \mathrm{s}$ when it entered Korean and Chinese.

\section{Direct English loans}

Both Korean and Japanese possess great numbers of loan-words from English, constituting over 5\% of the lexical store of Korean and up to 10\% of the lexical store of Japanese (Sohn 1994: 528, Hinds 1974: 93). The overwhelming majority of these words have entered Korean and Japanese since the end of World War II, and the influx is still continuing. Officially all but a few of the words in current usage in Korean have come directly from English. Before 1945, however, those English-derived words that existed in Korean had been introduced through Japanese, and so strictly speaking they were borrowed directly from Japanese. After 1945, Korean attitudes toward Japan, Japanese culture, and the Japanese language were hostile, and wherever possible native Japanese loan-words 
were purged and replaced either with native Korean formations or with loans from English. Moreover, Western loan-words that had been copied directly from the Japanese version were largely replaced by versions that were copied directly from the original Western language (Tanaka and Lee 1986: 127), such as the change sement'o $\Rightarrow$ shiment' $\breve{u}$ above. ${ }^{6}$ The purging process is slow, and despite official and recognized academic pressure to purify the language (see Pak 1984) and lists of correct forms (see for example Pak 1988), a great many earlier forms are still in popular use, and dictionary compilers may vary with regard to which copy of a particular English word they should include. For instance, the English word cutlet / $\mathbf{k} \wedge t l a t /$ first entered Korean as $k k a(s) s \breve{u}($ ressü) as a direct copy of the Japanese version katsu(retsu), which itself had been copied from English in the last century at around the same time as waishatsu '(white) shirt' and baketsu 'bucket'. Katsu(retsu) shows the characteristic early treatment of syllable-final English / $\mathrm{t} /$ as $t s u$, rather than as to as is now the case (see section 3.2. below), and is also an example of the process of truncation that Japanese often applies to overlong loan-words (see section 4.1. below). This form has not been fully purged from the contemporary language, but alongside it a form $k^{\prime}$ ót'üllet now occurs as a direct copy from English.

Moreover, alongside the direct copy $k k a(s)$ sŭ from Japanese (listed in Eccardt and Oh 1993) and the direct copy k'ót'üllet from English (listed in Kim 1977 and Pak 1988) exists a third possibility, k'at'üllet (listed in Minjungseorim 1972 and 1980), which, although it is largely copied from English, nevertheless preserves the earlier Japanese-derived vowel $a$. It is not an uncommon phenomenon in modern Korean for such hybrid Anglo-Japanese loan-words to emerge as a result of partial purging of Japanese influence from the language. As these words are no longer overtly Japanese in form - and in many cases the Japaneseinfluenced feature is reinforced by some aspect of English spelling they are often the forms that have gained the greatest currency. Various aspects of hybrid copying are discussed in section 4 below, ranging from such phonological hybrids as $k^{\prime}$ at'ullet to forms that now appear to be derived fully from English phonologically but show a Japanese origin morphologically.

It is helpful first of all to survey the regular correspondences between English and Korean and Japanese. It should be remembered that the rules below account for the copying of the vast majority of stressed vowels and consonants in English into the two languages. Unstressed vowels are problematic and are discussed in section 4.2.1 below. English forms are given in Received Pronunciation transcription, as the copies 
in Korean and Japanese are largely based on RP or a form of English close to RP. ${ }^{7}$

\subsection{Stressed vowels}

The stressed vowel correspondences between Korean and English and between Japanese and English are highly regular. There are some exceptions in both languages for one reason or another, but they are not discussed here as they are few. The table below lists the regular reflexes of the English vowels in the two languages. The convention $Q$ indicates that a following voiceless plosive (and in more recent loans also $s$ and $s h)$ is geminated. ${ }^{8}$

A note should be made that phonemic length is maintained in the Japanese copies, whereas in Korean the representation of English pure long vowels and /ov/ can be either long or short. The tendency in Korean is to pronounce and write these as short, and it is the short versions that Pak (1988) lists. Some earlier dictionaries (such as Minjungseorim 1972, but not Minjungseorim 1980) tend to mark length, although the prescription of shortened forms can be traced back to recommendations of the Chosono or Hakhoe (1940b: 9-10), produced in conjunction with recommended orthographic norms for native words and hanjar at the request of the press, publishers, and academics alike (1940a). Moreover, the longer versions are sometimes still used. The reason for shortening lies not in the English source dialect, but rather in the loss of phonemic length within the Korean language as a whole. Distinctions of phonemic length between pairs such as /nun/ 'eye' and /nu:n/ 'snow' are marked even in some textbooks of the language for Western learners (e.g. Martin and Lee 1969), although most textbooks make no mention of phonemic length (e.g. Vandesande 1968; Lukof 1982). However, most South Koreans neutralize the difference to varying extents (Sohn 1994: 452-453; Park 1994: 178-180). Moreover, even among those Koreans who distinguish phonemic length, the distinction is always neutralized in any syllable other than the first or stressed syllable (Lee 1989: 21-22; Martin 1992: 32-33). Consequently, phonemic length in loan-words, whether the initial syllable or subsequent, has also been neutralized.

In Japanese, on the other hand, long vowels occur in only a few native morphemes (as a result of the loss of an intervocalic $/ \mathrm{f} /, / \mathrm{w} /$, or $/ \mathrm{k} /$ ) but are widely found among Chinese-derived morphemes as compensatory lengthening after the loss of a syllable-final /p/ or / $\mathrm{y} /$ (Vance 1986: 56). The rules below list both the short and the long representations in Korean 
of log English vowels. Examples in section 4 will contain only the long vowe representations.

\begin{tabular}{|c|c|c|}
\hline English & Korean & Japanese \\
\hline l/ & i & $\mathrm{iQ}$ \\
\hline / & $\mathrm{u}$ & $\mathrm{uQ}$ \\
\hline le/ & e & $\mathrm{eQ}$ \\
\hline$/ \mathfrak{~} /$ & ae & $\mathrm{aQ}$ \\
\hline$|\Lambda|$ & ŏ & $\mathrm{aQ}$ \\
\hline $\mid \mathrm{p} /$ & 0 & $\mathrm{oQ}$ \\
\hline /i:/ & $\mathrm{i}(\mathrm{i})$ & $\bar{\imath}$ \\
\hline /u:/ & $\mathrm{u}(\mathrm{u})$ & $\overline{\mathrm{u}}$ \\
\hline /3:/ & ŏ(ŏ) & $\bar{a}$ \\
\hline /a:/ & $a(a)$ & $\bar{a}$ \\
\hline /o:/ & $o(0)$ & $\bar{o}$ \\
\hline |əv/ & $o(u)$ & $\bar{o}$ \\
\hline /av/ & $\mathrm{au}$ & $\mathrm{au}$ \\
\hline /el/ & ei & $\overline{\mathrm{e}} / \mathrm{ei}$ \\
\hline $\mid \mathrm{ot} /$ & oi & oi \\
\hline /al/ & ai & ai \\
\hline /1ә/ & iŏ & iya \\
\hline /ひə/ & uǒ & ua \\
\hline /દə/ & eŏ & ea \\
\hline /ö/ & oŏ & oa \\
\hline /ava/ & auŏ & awā \\
\hline
\end{tabular}

Rpresentative examples are given below:

(8)

\begin{tabular}{|c|c|c|c|}
\hline & $\begin{array}{l}\text { Korean } \\
\text { p'in }\end{array}$ & $\begin{array}{l}\text { Japanese } \\
\text { pin }\end{array}$ & $\begin{array}{l}\text { English } \\
\text { 'pin' }\end{array}$ \\
\hline$|\mathrm{v}|$ & p'udin & puddingu & 'pudding' \\
\hline & pel & beru & 'bell' \\
\hline $\mid \mathfrak{x} /$ & haem & hamu & 'ham' \\
\hline$/ \Lambda \mid$ & pǒsŭ & basu & 'bus' \\
\hline$/ \mathrm{p} /$ & mop & moppu & 'mop' \\
\hline /i:/ & k'ŭri(i)m & kurīmu & 'cream' \\
\hline /u:/ & sŭp’u(u)n & supūn & 'spoon' \\
\hline /3:/ & sŏ(ŏ)bisŭ & sābisu & 'service' \\
\hline /a:/ & $\mathrm{pa}(\mathrm{a})$ & bā & 'bar' \\
\hline /o:/ & ho(o)l & hōru & 'hall' \\
\hline /əu/ & t'o(u)sŭt'ŭ & tōsuto & 'toast' \\
\hline /av/ & pŭraun & buraun & 'brown' \\
\hline /el/ & reisŭ & rēsu & 'lace' ('race' \\
\hline
\end{tabular}




\begin{tabular}{|c|c|c|c|}
\hline 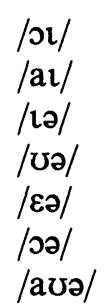 & $\begin{array}{l}\text { k'oin } \\
\text { p'ai } \\
\text { iŏrin } \\
\text { maenik'yuǒ } \\
\text { heǒ } \\
\text { toǒ } \\
\text { shauǒ }\end{array}$ & $\begin{array}{l}\text { koin } \\
\text { pai } \\
\text { iyaringu } \\
\text { manikyua } \\
\text { hea } \\
\text { doa } \\
\text { shawā }\end{array}$ & $\begin{array}{l}\text { 'coin' } \\
\text { 'pie' } \\
\text { 'earring' } \\
\text { 'manicure' } \\
\text { 'hair' } \\
\text { 'door' } \\
\text { 'shower' }\end{array}$ \\
\hline
\end{tabular}

Notice that whereas English possesses 11 distinct qualities of monophthong (six short, five long), Korean only distinguishes eight and Japanese only five. As a result, a number of phonemic mergers occur. In Japanese, $/ \mathfrak{x} /$ and $/ \Lambda /$ are consistently merged as $a, / 3: /$ and $/ \mathrm{a}: /$ as $\bar{a}$, and $/ \mathrm{o}: /$ and $/ \partial v /$ as $\bar{o}$. If Korean does not distinguish vowel length - as is commonly the case - then $/ \mathrm{l} /$ and $/ \mathrm{i}: /$ are merged, as are $/ \mathrm{v} /$ and $/ \mathrm{u}: /$, $/ \mathrm{\Lambda} /$ and $/ \mathrm{s}: /$, and $/ \mathrm{D} /, / \mathrm{o}: /$, and $/ \partial v /$. Note, however, that the distinction of quality between $/ \mathfrak{x} /$ and $/ \mathfrak{a}: /$ is maintained in Korean even when quantity is not.

\subsection{Consonants}

3.2.1. Prevocalic (initial or medial)

\begin{tabular}{|c|c|c|c|}
\hline (9) & English & Korean & Japanese \\
\hline & $/ \mathrm{p} /$ & $\mathrm{p}^{\prime}$ & $\mathrm{p}$ \\
\hline & /f & $\mathrm{p}^{\prime}$ & f \\
\hline & $/ t /$ & $\mathbf{t}^{\prime}$ & $\mathrm{t}$ \\
\hline & $/ \theta /$ & $\mathbf{s}$ & s \\
\hline & /s/ & $\mathbf{s}$ & $\mathbf{s}$ \\
\hline & $/ \mathrm{J} /$ & sh & sh \\
\hline & $/ \mathrm{t} \mathrm{f} /$ & ch' & ch \\
\hline & $/ \mathbf{k} /$ & $\mathrm{k}^{\prime}$ & $\mathbf{k}$ \\
\hline & $/ b /$ & $\mathrm{p} / \mathrm{b}$ & b \\
\hline & $/ \mathrm{v} /$ & $\mathrm{p} / \mathrm{b}$ & $b / v$ \\
\hline & /d/ & $t / d$ & d \\
\hline & /ర/ & $t / d$ & z \\
\hline & /z/ & $\mathrm{ch} / \mathrm{j}$ & z \\
\hline & $/ 3 /$ & $\mathrm{ch} / \mathbf{j}$ & $\mathrm{j}$ \\
\hline & /d3/ & $\mathrm{ch} / \mathrm{j}$ & $\mathrm{j}$ \\
\hline & /g/ & $\mathrm{k} / \mathrm{g}$ & $\mathrm{g}$ \\
\hline & $/ \mathrm{m} /$ & $\mathrm{m}$ & $\mathrm{m}$ \\
\hline & $/ \mathrm{n} /$ & $\mathrm{n}$ & $\mathbf{n}$ \\
\hline
\end{tabular}




$\begin{array}{llll}/ \mathrm{h} / & & \mathrm{h} & \mathrm{h} \\ / \mathrm{l} / & \text { init.: } & \mathrm{r} & \mathrm{r} \\ & \text { med.: } & \mathrm{ll} & \mathrm{r} \\ / \mathrm{r} / & & \mathrm{r} & \mathrm{r} \\ \mathrm{/j} / & & \mathrm{y} & \mathrm{y} \\ / \mathrm{w} / & & \mathrm{w} & \mathrm{w}\end{array}$

In both Japanese and Korean, $s$ and $s h$ are separate phonemes, but before $i$ in Japanese and $i$ or wi in Korean, only sh is possible, causing English seat and sheet to merge in Japanese as shito and in Korean as $\operatorname{sh} i(i) t^{\prime} u$. Neither cooccurs phonetically with a following $y$.

The unaspirated voiceless and voiced consonants in the Korean column are allophones of the same phoneme, represented in hangül by the same letter, but by the two letters in the McCune-Reischauer romanization.

In more recent loans, either $b$ or $v$ is possible in Japanese to represent English $/ \mathrm{v} /$, the former representing a more conservative variety of Japanese, the latter a more innovating variety. Older loans have only $b$.

3.2.2. Preconsonantal. Epenthesis characterizes the treatment in both languages of consonant clusters

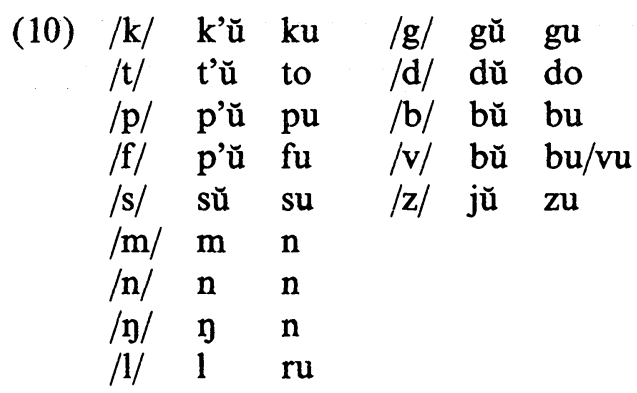

Japanese does not allow any clusters other than those of which the first vowel is a nasal. The exception is that English /ts/ and /dz/ are treated as $t s$ and $z$ in Japanese, which are generally treated as single phonemes. Korean allows several clusters without epenthesis, ammely $l C$, $n C, m C, \eta C, p t^{\prime}, k t^{\prime}, k s, k s h, p s$, and $c h^{\prime}$, the last corresponding to English /ts/. The following examples are representative:

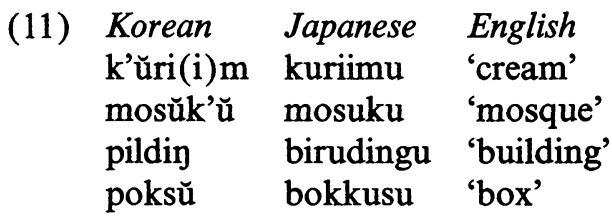


3.2.3. Final. Similarly, a final consonant in English is regularly articulated by means of a paragogic vowel. The normal vowel is $\breve{u}$ in Korean and $u$ (or after a dental plosive $o$ ) in Japanese. Both languages prefer $i$ after an original palato-alveolar consonant (although in Japanese $u$ tends to be used in more recent loans).

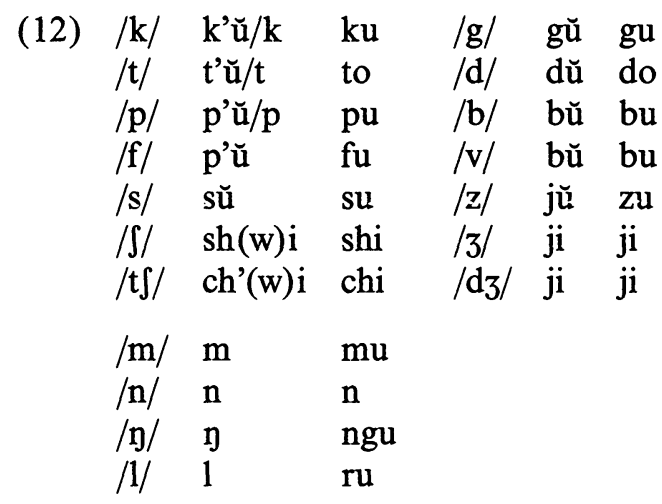

\subsection{The role of English in modern Korean and Japanese}

Honna (1995: 52) suggests that there are three main roles that English loan-words perform in Japanese: as technical terms; to represent new concepts; and as a form of euphemism that coexists with a native word but is free of the connotations with which the native word has become loaded. For instance, the area of computing terminology is particularly rich in loan-words in both Japanese and Korean:

(13)

$\begin{array}{ll}\text { English } & \text { Japanese } \\ \text { 'computer' } & \text { konpyūtā } \\ \text { 'monitor' } & \text { monitā } \\ \text { 'software' } & \text { sofutowea } \\ \text { 'bit' } & \text { bitto } \\ \text { 'micro-processor' } & \text { maikuropurosessāā } \\ \text { 'server' } & \text { sābā } \\ \text { 'multimedia' } & \text { maruchimedia } \\ \text { 'application' } & \text { apurikēshon }\end{array}$

Korean

k'ŏmp'yut'ŏ monit'̌ sop'ŭt'ǔweŏ pit'ŭ maik'ŭrop'ŭrosesŏ sŏbǒ mŏlt'imidiŏ aep'ŭllik'eishŏn

Existing Japanese and Korean words could have been used instead of an English loan for the last example, but the English word seems to have been preferable because it was not loaded with the connotations that the native words have. 
To Honna's three categories, which to a large extent can apply to any language, a fourth category of "fashionable" English that is particularly extremely prevalent in Japanese and Korean must be added. This category covers the vast number of English or pseudo-English elements that occur in popular magazines and television, especially in advertising. Apart from its all-pervasiveness, "fashionable" English is distinctive from other loans in two ways. First, it includes not only assimilated loan-words but new unassimilated elements, often combined. Second, not only do such "loans" represent the lexical level, but also whole phrases or clauses occur, sometimes alone, sometimes embedded in a syntactically Japanese/Korean sentence.

A short but representative survey of newspaper advertisements in South Korea's Chosón Ilbo (consisting of all advertisements covering more than a quarter of a page in the 22 and 23 August 1994 main editions) reveals a wide use of English. Out of exactly 50 advertisements, 27 had at least one English word in the main caption(s) (excluding two holiday companies with foreign place-names in their main caption). Of these, 14 had more than one word of English. A few of these words occur frequently and are thoroughly assimilated into everyday Korean, such as p'aeshǒn 'fashion', püraend $\breve{u}$ 'brand', and ap'at' $\breve{u}$ 'apart(ment)'. Other uses of English, though, would not be found in everyday Korean, such as the use of pesút' 'u 'best' and seil 'sale' in the main caption of an advertisement for a furniture retailers:

$$
\begin{array}{lll}
\text { pesŭt'ŭ ch'imdae/sop'a p'agyŏk } & \text { seil } \\
\text { best bed sofa unprecedented sale }
\end{array}
$$

The main caption to one holiday company's late summer offerings is entirely "English," though with a morpheme reduplication that would not occur in any English advertising:

(15) rŏbŭ-rŏbŭ hŏnimun

love- love honeymoon

Fashion, with its association with Western chic, is particularly full of "fashionable" English. For example, an advertisement for a lipstick called Chaejŭ Wain 560 'Jazz Wine 560', which includes such words as süt'ail 'style', aeksent' $\breve{u}$ 'accent', and meik' ǔŏp 'makeup', carries the slogan

$$
\begin{aligned}
& \text { t'ŭrit'ŭmŏnt'ŭ t'aib-ŭi ripsŭt'ik } \\
& \text { treatment type GEN lipstick }
\end{aligned}
$$

The only Korean morpheme in this entire phrase is the genitive particle -ŭi. Another fashion company uses the words p'at'ünŏ 'partner', mak'et'in 'marketing', p'aeshŏn 'fashion', and (in Roman script) "'94 Fall 
Collection." The phrase t'üraedishŏnal-jŏk sanp'um 'traditional goods' occurs, attaching the Korean adjectival suffix -jök to an English adjective.

However, most noticeable in the sample is the fact that of the 46 advertisements that consisted of Korean companies/brands, only 23 had purely Korean names, whereas 16 had English names, three had Korean names accompanied by English translations, and four had names that were from another European language. Of the 16 English names, five were written only in hangŭl, five were written only in the Roman script, and six were written in both. Even acronyms such as KAMCO (=Korea Automotive Motor Corporation) were transcribed into hangül: K'amk'o. Some of the names would hardly be found in such contexts or with such syntax in an English-speaking country:

$\begin{array}{ll}\text { Joy Club } & \text { (holiday company) } \\ \text { Semi-Line \& Knocker } & \text { (fashions) } \\ \text { Best Sports } & \text { (beds, couches, and chairs) } \\ \text { Bonny Joy } & \text { (children's clothes) } \\ \text { Sale-Sale Shopping Mall } & \text { (shopping mall) }\end{array}$

One major electricals company showed a preference for un-English compounds, often portmanteaux, such as At'ǔbijyŏn 'Art-(Tele)vision' and k'omyunik'at'op'ia 'communica(tion-u) topia'.

What factors have contributed toward the current prevalence of English in Korean? In discussing the situation in Japanese, Honna (1995: 54-61) considers the three main factors to be the existence of a separate script in Japanese for writing foreign words (katakana), the restriction imposed upon neoclassical compounding by the reduction of the number of Chinese characters in use, and the compulsory nature of English education.

I would argue that the contribution of the first two to either Japanese or Korean is negligible. First, the ease with which English words can be written in Japanese - which is Honna's first point - is less a direct result of the existence of katakana than a result of the existence of a set of transcription rules that have become established for this purpose. Korean also possesses such a set of rules but does not have a separate script for representing loan-words, yet it does not seem to have been hampered by this lack. Second, although the number of Chinese characters prescribed in Japan and Korea is now no more than two thousand, in most cases where an English word has been adopted as a technical term it would not be difficult to find appropriate morphemes among the two thousand characters that could have been combined to represent the appropriate meanings. In China, most computer terminology has been coined from Chinese roots, and in many cases more than one form has 
been coined among different Chinese communities (Liu 1986: 40-41); yet in most cases the component morphemes are among the two thousand characters in Japanese and Korean.

I would argue that the two most important factors in the cases of both Korean and Japanese are as follows. First, the third of Honna's three categories, the compulsory status of English education, has resulted in Koreans and Japanese having an extensive knowledge of English; even though the chances to speak in English outside the classroom environment are small, this has made English very familiar within the countries. Second, as Haarmann (1986: 110) points out, the widespread use of English in advertising is due to the fact that, because the native language is the vehicle of everyday communication, native words are emotionally neutral, whereas elements from Western languages are more emotive, more cosmopolitan, and more modern in their feel. Although much of the English found in Japanese and Korean advertising is not found in the everyday languages, many words do make the transition. Haarmann's (1986: 119) assertion that "many terms which have been assimilated as borrowings in colloquial Japanese became popular among Japanese native speakers because of their frequent usage in Japanese mass media" is becoming equally true of Korean.

\section{Hybrid Anglo-Japanese loans}

The regular correspondences outlined above apply to incorporation of the vast majority of English words into Japanese and Korean and the transcription into Japanese katakana or Korean hangŭl of English names.

Naturally, there are largely isolated cases where the reflex of an English word is not the one that would normally be expected. A sizable number of exceptions in Korean, however, may be explained in terms of hybrid loaning.

In the sections below, various types of hybridization are discussed. The Japanese influence in most cases is due to the spelling in katakana. In some of these cases, the katakana spelling can be traced back to the way in which the English original is spelled (Roman-based), such as in the case of blouse below. In the others the Japanese form is not based on English spelling (Kana-based).

\subsection{Consonant irregularity}

There are few consistent irregularities in the treatment of English consonants. This is largely due to the fact that the phoneme-grapheme relation- 
ship of consonants in English is relatively accurate. However, one inconsistency is noticeable in Japanese, namely whether graphic $s$ represents $/ \mathrm{s} /$ or $/ \mathrm{z} /$, and a number of misinterpretations have become established in Japanese. The same misinterpretations have been passed into Korean and become established in that language as well.

4.1.1. Misinterpretation of English -s. Syllable-final $-s$ in English sometimes represents /s/, sometimes /z/. Normally, both Japanese and Korean maintain the distinction, as $-s u$ and $-z u$ in Japanese and as $-s \check{u}$ and $-j \check{u}$ in Korean. In a few cases, Japanese copies an $-s$ representing /z/ according to spelling:

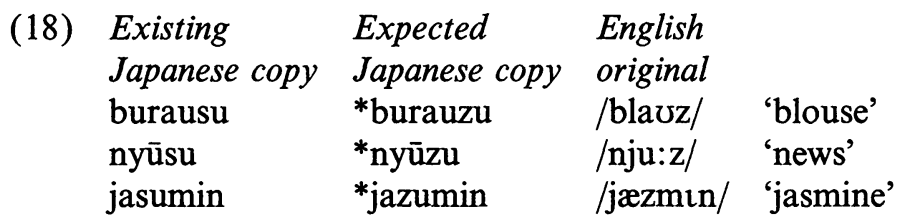

In one common expression, Japanese has done the reverse and hypercorrected a syllable-final $-s$ that is pronounced $/ \mathrm{s} /$ as though it were a $/ \mathrm{z} /$ :

$$
\text { kurōzu-appu *kurōsu-appu /kləusıp/ 'closeup (shot)' }
$$

The Korean versions of these words are hybrid. For example, blouse /blauz/ would be expected to have the reflex *püllaujŭ in Korean if it had been copied fully from the English, representing the $/ z /$ regularly as $-j \check{u}$ as in the examples above. If, on the other hand, blouse had been directly copied from the Japanese version, it would be expected to have the reflex *pŭraus̆̌, representing Japanese $-s u$ as $-s \breve{u}$ and continuing the merger of English / $1 /$ with / $r /$ in Japanese as $r$. Neither of these forms occurs. The Korean reflex is pŭllausŭ, a true hybrid, derived directly neither from English nor from Japanese. The - $l l$ - is from English, yet the $-s$ - is from Japanese. The actual reflexes in Korean of all four words above, together with the expected reflexes if they had been copied fully from English or from Japanese, are

$\begin{array}{llll}\text { Hybrid copy } & \text { Expected copy } & \text { Expected copy } & \text { English } \\ \text { in Korean } & \text { from English } & \text { from Japanese } & \text { original } \\ \text { pŭllausŭ } & \text { *pŭllaujŭ } & \text { 'pŭrausŭ } & \text { 'blouse' } \\ \text { nyuusŭ } & \text { *nyuujŭ } & \text { nyuusŭ } & \text { 'news' } \\ \text { chaesŭmin } & \text { *chaejŭmin } & \text { *chasŭmin } & \text { 'jasmine' } \\ \text { k'ŭlloujŭ-ŏp } & \text { *k'ŭllousŭ-ŏp } & \text { *kkŭroujŭ-ap'ŭ } & \text { 'close-up' }\end{array}$

Note that the nyuu- of nyuusŭ could be derived regularly either from English or from Japanese, and as such should perhaps be considered not 
as a hybrid loan but rather as a full copy from the Japanese equivalent. It is included here as it belongs to the same pattern as püllausŭ.

4.1.2. Representation of rhoticity. Both Japanese and Korean copying of English words reflect the fact that syllable-final $-r$ does not represent a consonant in the surface phonology in Received Pronunciation:

$\begin{array}{lll}\text { Korean } & \text { Japanese } & \\ \text { k'aunt'ŏ } & \text { kauntā } & \text { 'counter' } \\ \text { paat'endŏ } & \text { bāten(dā) } & \text { 'bartender' } \\ \text { sŭp'iik'ó } & \text { supīkā } & \text { 'speaker' }\end{array}$

In some Japanese versions, a syllable-final $-r$ is represented as $-r u$. Most of these copies are derived not from English, but from another European language, particularly French:

$\begin{array}{llll}\text { Japanese copy } & \text { Expected copy } & \text { English } & \text { French } \\ \text { from French } & \text { from English } & & \\ \text { korusetto } & { }^{*} \text { kōsetto } & \text { 'corset' } & \text { corsette } \\ \text { gētoru } & { }^{*} \text { gētā } & \text { 'gaiter(s)' } & \text { guêtres }\end{array}$

Occasionally, the $-r u$ is most likely to be a very early loan, and it is unclear as to whether it is spelling-based or derived from an American pronunciation or from German:

$\begin{array}{llll}\text { Existing copy } & \text { Expected } & \text { English } & \\ \text { from Japanese } & \text { Japanese copy } & \text { original } \\ \text { morutaru } & * \text { mōtā } & \text { /mo:tə/ 'mortar' }\end{array}$

Similarly, the name for the Roman letter $R$ is $\bar{a} r u$, an early loan from English, and not ${ }^{*} \bar{a}$, and although such acronyms as $P R$ have been borrowed much more recently, Japanese has borrowed only the written form and pronounces each element according to the way in which it already exists in Japanese (reminiscent of Sino-Japanese formations), hence

$$
\text { pīāru *pīà /pi:a:/ 'PR' }
$$

Finally, the English word iron /atən/ would be expected to produce a form *aion. In fact, the word has been borrowed twice into Japanese, once with an irregular insertion of a spelling-based $-r$-, and once with an irregularly non-spelling-based treatment of $/ \mathrm{o} /$. Loan-words in Japanese frequently display semantic narrowing, as they are often borrowed in just one sense, and often they compete with native words. So it is that the two copies of iron have entered Japanese with quite different senses: 


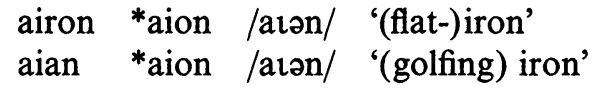

In Korean, it is typically the case that wherever Japanese adds $-r u$, the Korean version also adds -rŭ. Similarly, English iron is borrowed in two forms, one with $-r$ - and one without $-r$-, in the same senses as the Japanese. Notice, however, that the form without $-r$ - copies English /o/ regularly as $-\check{o}$ - rather than copying the Japanese $-a$-. These are hybrid loans, and Japanese influence is unmistakeable:

$\begin{array}{lll}\text { Korean } & \text { Japanese } & \text { English } \\ \text { k'orŭset } & \text { korusetto } & \text { 'corset' } \\ \text { ket'ŭrŭ } & \text { gētoru } & \text { 'gaiter(s)' } \\ \text { morŭt'arŭ } & \text { morutaru } & \text { 'mortar' } \\ \text { p'iiaarŭ } & \text { pīāru } & \text { 'PR' } \\ \text { airon } & \text { airon } & \text { '(flat-)iron' } \\ \text { aiŏn } & \text { aian } & \text { '(golfing) iron' }\end{array}$

\subsection{Vowel irregularity}

In contrast to the relative regularity of grapheme-phoneme correspondences of English consonants, English vowels notoriously demonstrate a great deal of variety, and it is in regard to vowels that a great many Japanese-influenced hybrids persisted.

4.2.1. Roman-based. The Japanese treatment of English stressed vowels is extremely consistent, although there are a few largely isolated inconsistencies. For instance, though English / $\mathfrak{l} /$ usually corresponds to $o i$ in Japanese, the most common word in English containing / $\mathrm{ol} /$, boy, is realized in Japanese with lengthening as $b \bar{o} i$.

The treatment of English unstressed vowels, however, shows a great deal of variety in Japanese. In particular, / $/$ /, the most frequently occurring vowel in English, is commonly realized in Japanese as $\bar{a}, a$, or or $e$ :

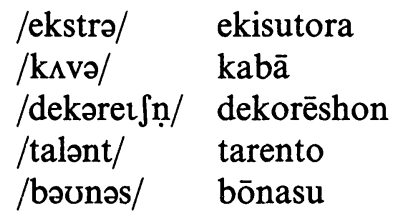

It is impossible to find phonemic/phonetic motivations for this variation. The motivation is in fact spelling-based. The $a$ in ekisutora correlates 
with the $a$ in the English spelling, the $\bar{a}$ in $k a b \bar{a}$ with the $e r$ in the English spelling, and so on.

Essentially, Japanese is a mora-timed language and lacks both unstressed vowels in general and a vowel that corresponds to English schwa. As a result, Japanese reinterprets unstressed syllables as if they were stressed on the basis of spelling, and these reinterpreted forms are then copied into Japanese quite regularly. ${ }^{10}$

\begin{tabular}{|c|c|c|c|c|c|}
\hline $\begin{array}{l}\text { ', } \\
\text { ration' }\end{array}$ & $\begin{array}{l}\text { a/ } \\
/ \\
\text { ret } \int \mathrm{n} /\end{array}$ & & $\begin{array}{l}\text { ræ/ } \\
\text { 3:/ } \\
\text { pretsṇ/ } \\
\text { nt/ }\end{array}$ & $\begin{array}{l}\Rightarrow \\
\Rightarrow \\
\Rightarrow \\
\Rightarrow \\
\Rightarrow\end{array}$ & shon \\
\hline
\end{tabular}

The orthographic/phonemic correspondences may be summarized as

/ə/ spelled 'er/ar/re/ure/our' $\Rightarrow \bar{a}$

e.g. batā 'butter', dans $\bar{a}$ 'dancer', esukarēt $\bar{a}$ 'escalator', jesuchā 'gesture', konsāto 'concert', sentā 'center'

$/ \partial /$ spelled ' $\mathrm{a}$ ' $\Rightarrow \mathrm{a}$

e.g. amachua 'amateur', infuruenza 'influenza', insutanto 'instant', negachibu 'negative', puraibash̄̄ 'privacy', raiburari 'library'

$/ \partial /$ spelled 'o' $\Rightarrow 0$

e.g. barukonī 'balcony', dekorēshon 'decoration', epuron 'apron', kondensu miruku 'condensed milk', purodakushon 'production', romansu 'romance'

/ə/ spelled 'e' $\Rightarrow \mathrm{e}$

e.g. nansensu 'nonsense', tarento 'talent'

$/ \partial /$ spelled 'u' $\Rightarrow a$

e.g. bōnasu 'bonus'

In Korean, however, the vowel $\check{\delta}$ corresponds closely to English schwa, and so Korean generally copies English words according to pronunciation, and not spelling. Hence, the Korean versions of extra, cover, decoration, talent, and bonus are

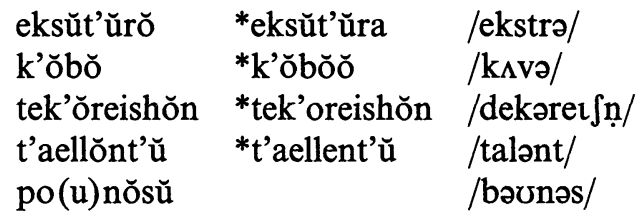

However, some English nouns enter Korean not with $\check{o}$, but with the same vowel that the Japanese form possesses: 
Existing copy in Korean

popura

daiyaru

nikkeru p'op'ǔlla

taial

nik'el
Expected copy English in Korean

*p'op'üllŏ

*taiŏl

*nik’ŏl 'poplar'

'dial'

'nickel'

In each of the three examples above, the vowel chosen to represent schwa in English is the same as that which is used in the Japanese equivalent, yet English /1/, which Japanese represents as $r$, is maintained in Korean. The possible correspondences between English and Korean are summarized below:

/ə/ spelled 'er/ar/re/ure/our' $\Rightarrow \breve{o}$

e.g. pŏt'ó 'butter', taensŏ 'dancer', esǔk'ólleit'ŏ 'escalator', chesǔch' $\breve{o}$ 'gesture', $k$ 'onsót' $\breve{u}$ 'concert', sent' $\breve{o}$ 'center'

/ə/ spelled 'a' $\Rightarrow \mathrm{a}$

e.g. amach'uó 'amateur', inp'ǔlluenja 'influenza', negat'ibŭ 'negative'

regardless of spelling $\Rightarrow \check{o}$

e.g. insŭt'ŏnt'ŭ 'instant', p'üraibŏshi 'privacy', raibŭrŏri 'library'

$/ \partial /$ spelled 'o' $\Rightarrow 0$

e.g. palk'oni 'balcony', k'ondensŭt'ü milk' $\breve{u}$ 'condensed milk', p'ürodŏkshŏn 'production', romaensŭ 'romance'

regardless of spelling $\Rightarrow \check{o}$

e.g. tek'ŏreishŏn 'decoration', eip'ürŏn 'apron', p'ürodŭkshŏn 'production'

/ə/ spelled 'e' $\Rightarrow \mathrm{e}$

e.g. nŏnsensŭ 'nonsense'

regardless of spelling $\Rightarrow \breve{o}$

e.g. t'aellont' $\breve{u}$ 'talent'

/ə/ spelled 'u' $\Rightarrow$ o

e.g. pounŏs̆̌ 'bonus'

There are two main reasons for the existence of spelling-based copies of schwa in Korean. The first is simply that in many words even in English schwa may be pronounced according to spelling. A common example of this is the Latin-derived prefix com- ( con-), which, when unstressed, varies freely between $/ \mathrm{kəm} /$ (or $/ \mathrm{kən} /$ ) and $/ \mathrm{kpm} /$ (or $/ \mathrm{kpn} /$ ). Copies in Korean usually reflect the latter pronunciation as $k$ 'on- or k'om-: 


$\begin{array}{ll}\text { k'omyunik'eishŏn } & \text { 'communication' } \\ \text { k'omediŏn } & \text { 'comedian' } \\ \text { k'omp'yut'ǒ } & \text { 'computer' } \\ \text { k'omp'ŭresŏ } & \text { 'compressor' }\end{array}$

In some cases, however, a form containing $k^{\prime}$ ŏm- (or $k^{\prime} \breve{o n}^{\prime}$ ) occurs:

(34) k'ŏmishŏn 'commission'

k'ŏndishŏn . 'condition'

The second reason is that the spelling-based copy is due to Japanese influence. When two schwas are present in the English, both are very frequently reinterpreted as though they were stressed. Common examples include

$\begin{array}{llll}\text { Korean } & \text { Japanese } & & \\ \text { k'amera } & \text { kamera } & \text { /kæmərə/ } & \text { 'camera' } \\ \text { korilla } & \text { gorira } & \text { /gərılə/ } & \text { 'gorilla' }\end{array}$

Note that although the Korean forms are mostly copies from Japanese, the distinction between $/ \mathrm{r} /$ and $/ 1 /$ in English, neutralized in the Japanese forms as $r$, is reinstated in Korean. As mentioned earlier, native Japanese words normally contain short vowels only, and so kamera and gorira fit the native pattern. As a result, there are many examples of English words that contain not just a schwa but a long vowel that are reinterpreted with stressed spelling-based short vowels throughout. Generally these words are carried over into Korean with the same vowels as in English:

$\begin{array}{ll}\text { (36) k'amelleon } & \begin{array}{l}\text { kamereon 'chameleon' } \\ \text { pija }\end{array} \text { biza } \\ \end{array}$

There are other examples of English long vowels or diphthongs being shortened in Japanese. In many of these, the vowels of two syllables occur in succession without an intervening consonant, such as /ouetsis/ oasis or $/ \mathrm{ni}: \mathrm{pn} /$ neon. The sequence of two long vowels (or four vowel morae) that a form ${ }^{*} \bar{o} \bar{e}$ shisu would have is contrary to the ideal CVCV structure of Japanese, and there are only a few words in common usage in Japanese with two long vowels, such as $h \bar{o} \bar{o}$ 'pope'. Again, Korean normally copies the Japanese vowels throughout:

$$
\begin{array}{lll}
\text { oashisŭ } & \text { oashisu 'oasis' } \\
\text { neon } & \text { neon } & \text { 'neon' }
\end{array}
$$

4.2.2. Kana-based. There are a number of cases of English loan-words in Japanese that contain unusual copies of an English vowel. In many cases, the unusual vowels are copied into Korean. Examples include 
(38)

$\begin{array}{llll}\text { t'ǒŏbin } & \text { tãbin } & \text { /t3:bain/ } & \text { 'turbine' } \\ \text { pui } & \text { bui } & \text { /bol/ } & \text { 'buoy' } \\ \text { mishin } & \text { mishin } & \text { /məSi:n/ } & \text { '(sewing) machine' } \\ \text { orenji } & \text { orenji } & \text { /orund3/ } & \text { 'orange' } \\ \text { k'akt'eil } & \text { kakutēru } & \text { /knktell/ } & \text { 'cocktail' }\end{array}$

Of these, the copies of turbine, buoy, and cocktail suggest an American English origin, while the other forms are difficult to explain. A German or French origin for $t^{\prime}$ ŏobin/täbin might explain the choice of the second vowel, but the first vowel $\check{o} \check{o} / \bar{a}$ can only be copied from English.

One final case is that of the Latin-derived suffix -ium. The suffix is pronounced either as $/ \mathrm{r} ə \mathrm{~m} /$ in all cases or as $/ \mathrm{j} ə \mathrm{~m} /$, although the latter pronunciation does not occur if the combination is preceded by a consonant cluster. Hence, uranium is pronounced /joreınıəm/ or /jureinjəm/, but cadmium is pronounced only as / $\mathrm{kædm}$ təm/. The Japanese copies of these words are distinctively spelling-based throughout, producing uraniumu (rather than *yurēniumu) and kadomiumu. In practice, however, the combination $i u$ is alien to Japanese, and words that historically contained the combination have changed to $y \bar{u}$, and the same change has been applied to -iumu in pronunciation, even in such cases as kadomiumu:

$\begin{array}{llll}\text { arumi(niumu) } & \text { pronounced } & \text { arumi(nyūmu) } & \text { 'aluminium' } \\ \text { uraniumu } & \text { pronounced } & \text { uranyūmu } & \text { 'uranium' } \\ \text { maguneshiumu } & \text { pronounced } & \text { maguneshūmu } & \text { 'magnesium' } \\ \text { kadomiumu } & \text { pronounced } & \text { kadomyūmu } & \text { 'cadmium' } \\ \text { puranetariumu } & \text { pronounced } & \text { puranetaryūmu } & \text { 'planetarium' } \\ \text { zeraniumu } & \text { pronounced } & \text { zeranyūmu } & \text { 'geranium' }\end{array}$

Korean has copied the vowels of the Japanese forms throughout. Not only are the vowels in English uranium copied according to the Japanese version as $u$ and $a$ rather than after the English pronunciation as $y u$ and $e i$, the / $/ 2 m /$ is copied as -yum and not as -iüm, as would be expected (compare $p$ 'ürijüm for English prism): ${ }^{11}$

(40)

$\begin{array}{ll}\text { alluminyum } & \text { 'aluminium' } \\ \text { uranyum } & \text { 'uranium' } \\ \text { magŭneshum } & \text { 'magnesium' } \\ \text { k'adŭmyum } & \text { 'cadmium' } \\ \text { cheranetlaryum } & \text { 'planetarium' }\end{array}$

\subsection{Japanese word-formation processes}

The Anglo-Japanese loans discussed above have been borrowed neither directly from English nor fully via Japanese but rather contain character- 
istics that are typical of both languages. A final major category of hybrid loans consists of words of which many are fully derived from English in terms of their phonemic representation - although others may also be phonetically hybrid - but which display Japanese word-formative processes. The two main varieties are truncated loans and lexemes known in Japan as wasei eigo 'made-in-Japan English'.

4.3.1. Truncation. The typical native Japanese noun has a two-syllable CVCV structure, although there are several CV and CVCVCV nouns, and therefore compounds typically have a four-syllable CVCV-CVCV structure. The only consonant clusters allowed are word-medial twoconsonant clusters of which the first element is the syllabic nasal $n$, which phonetically is homorganic with the following consonant. Native Korean nouns exhibit a wider variety of patterns, although the vast majority of nouns typically consist of between one and three syllables, and although Korean allows many more clusters than Japanese, it is still comparatively poor in the number of clusters that are allowed, and word-initial clusters, word-final clusters, and three-consonant clusters are disallowed. ${ }^{12}$ The Chinese loan-words in both languages, or words created in Japan or Korea from Chinese morphemes, are largely bimorphemic. ${ }^{13}$

The general Japanese and Korean tendency for nouns to consist of between one and three syllables with limited possibilities for consonant clustering has been disrupted by the great influx of western loan-words into the languages. Large numbers of extremely long and awkward loanwords have emerged through the regular use of epenthetic vowels to break up unacceptable consonant clusters and of paragogic vowels to avoid final consonants. Thus the monosyllabic strike is represented in both Japanese and Korean as five morae:
Japanese: su-to-ra-i-ki
Korean: sŭ-t'ŭ-ra-i-k'ŭ

The Japanese response to this has to be to truncate many such unwieldly words to a more acceptable Japanese structure. ${ }^{14}$ For example, the English words below would be expected to give the Japanese reflexes listed to their right:

\begin{tabular}{|c|c|c|}
\hline $\begin{array}{l}\text { 'sion' } \\
\text { bike'15 } \\
\text { ' } \\
\text { 'nstration' } \\
\text { ion' }\end{array}$ & 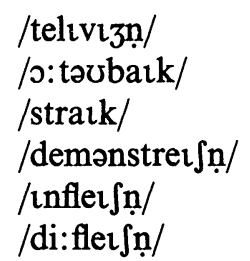 & $\begin{array}{l}\text { terebijon } \\
\text { *ōtobaiki } \\
\text { sutoraiki } \\
\text { demonsutorēsh } \\
\text { infurēshon } \\
\text { defurēshon }\end{array}$ \\
\hline
\end{tabular}




$\begin{array}{lll}\text { 'proposal' } & \text { /prə/ppəozl/ } & \text { *puropōzaru } \\ \text { 'crankshaft' } & / \text { kræykjæft/ } & \text { *kurankushafuto }\end{array}$

Although some of these do exist, others are not normally found in Japanese in their full form. Rather, truncated forms for all are more common in the spoken language: ${ }^{16}$

$\begin{array}{ll}\text { terebijon } & \Rightarrow \text { terebi } \\ \text { *ōtobaiki } & \Rightarrow \text { otobai } \\ \text { sutoraiki } & \Rightarrow \text { suto } \\ \text { demonsutorēshon } & \Rightarrow \text { demo } \\ \text { infurēshon } & \Rightarrow \text { infure } \\ \text { defurēshon } & \Rightarrow \text { defure } \\ \text { *puropōzaru } & \Rightarrow \text { puropōzu } \\ \text { *kurankushafuto } & \Rightarrow \text { kuranku }\end{array}$

The common Korean reflexes for the same English words often also show the same truncation, giving

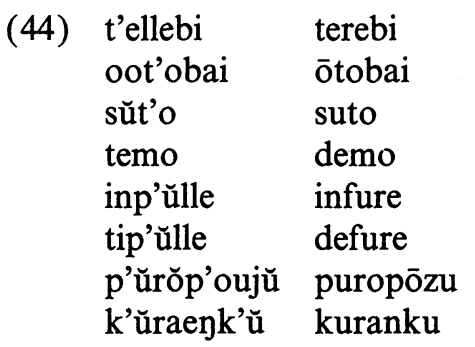

The truncation is clearly influenced by Japanese. However, in most cases the phonology of the words is English-based. Thus, the English distinctions of / $/ 0: /$ vs. /ov/ represented in *autobike and proposal above are maintained in Korean as $o o$ and $o u$ when vowel length is indicated, even though in Japanese the vowels are obligatorily merged as $\bar{o} .^{17}$ Similarly, the distinction between English $/ 1 /$, as in inflation, and / $r /$, as in crank, is neutralized in the Japanese representations but is maintained in Korean in accordance with the English-Korean correspondence rules. Again, however, both patterns for the treatment of unstressed vowels are represented: the unstressed vowels represented in tip'ülle and p'ürŏp'oujŭ are based on the sound of the English (as opposed to Japanese defure and puropōzu), whereas those in t'ellebi and oot'obai are based on the spelling of the English (through the influence of Japanese).

Full forms of some of the above, such as inp'ülleishŏn, tip'ülleishŏn and especially t'ellebijorn are also found in Korean, whereas the full forms of temo or oot'obai are either very uncommon or do not exist. Note that 
the full form from English strike would have developed as *süt'oraik'i if it had been borrowed in its Japanese form. The form that actually occurs in Korean is süt'üraik' $\breve{u}$ with the regular epenthetic/paragogic vowel $\breve{u}$ throughout, showing no influence from Japanese. ${ }^{18}$ Nevertheless, the truncated form is not ${ }^{*}$ sŭt' $\breve{u}$, which might be expected if the truncation had occurred within Korean, but sŭt'o, preserving the $o$ as the regular Japanese epenthetic/paragogic vowel after $t$ or $d$.

The following three very common loan-words in Korean phonologically fully copy the English original and yet are truncated through the influence of the Japanese version.

$\begin{array}{lll}\text { Korean } & \text { Japanese } & \text { English } \\ \text { ap'aat'ŭ } & \text { apāto } & \text { 'apart(ment)' } \\ \text { oubǒ } & \overline{o b a ̄ a} & \text { 'over(coat)' } \\ \text { p'ǒŏmŏ } & \text { pāma } & \text { 'perma(nent wave)' }\end{array}$

Although the morphemes apart and over occur in English, they are not used as truncations for apartment or overcoat respectively. Permanent wave in English is commonly abbreviated to perm, but an English form *perma, which underlies both the Japanese and the Korean versions, does not occur.

Some truncated loans, however, fully copy Japanese in both their phonology and their truncation: ${ }^{19}$

$\begin{array}{lll}\text { ero } & \text { ero } & \text { 'ero(ticism)' } \\ \text { nega } & \text { nega } & \text { 'nega(tive)' } \\ \text { k'ombi } & \text { konbi } & \text { 'combi(nation)' } \\ \text { p'ŭro } & \text { puro } & \text { 'pro(fessional/letariat/gram)' } \\ \text { taia } & \text { daiya } & \text { 'dia(gram/mond)' }\end{array}$

Of these, p'üro and taia are worthy of comment. The phonology of p'üro suggests that it has entered Korean from Japanese puro, since derivation from the English truncated form pro /pros/ would give the nonexistent form * ${ }^{*}$ 'urou in the same way that show / Jəu/ has given shou. $P$ 'uro is given by the Essence dictionaries as an abbreviation of three different words in English: professional, proletariat, and program. Of these, only the first exists in a truncated form in English. Japanese, however, frequently abbreviates all three as puro, as well as four other words (see Miller 1967).

The case of taia is similar to that of süt'o mentioned above, in that its truncated form is copied from the Japanese with a spelling-based $a$ representing English schwa. However, the full Korean version for diagram, taiŏgŭraem (= Japanese daiyaguramu), regularly copies the English throughout and represents the English schwa with $\breve{o}$. The full version is 
nevertheless a hybrid loan for reasons explained in section 4.3.3 below. The full version for diamond, taiamond $\breve{u}$ (= Japanese daiyamondo), retains the Japanese-influenced representation of two English schwas but does not display Japanese influence in the representation of the final /d/ of the English.

4.3.2. Wasei eigo. It was mentioned in section 2.3 that Japanese has made extensive use of bound Chinese-derived morphemes to create new words that do not exist in Chinese. The tradition has also been, extended to English-derived morphemes. There are a number of very common compound words in Japanese that are made from combining English elements that are not found together in English. An example is that of Japanese ótobai and Korean oot'obai 'motorbike' above, derived from combining auto- with bi(ke) in English, although *autobike is not found in English. This kind of English word is known as wasei eigo, 'made-inJapan English'. Other examples are

$\begin{array}{lll}\text { bōrupen } & \text { *ball-pen } & \text { 'ball-point pen, biro' } \\ \text { shāpupenshiru } & \text { *sharp pencil } & \text { 'propelling pencil' } \\ \text { sararīman } & \text { *salary-man } & \text { 'white-collar worker' }\end{array}$

Although the words do not exist in English, Korean has borrowed them from Japanese. As is usual among hybrid loans, the vowels and the $/ 1 /: / r /$ distinction in the Korean versions reflect fully the English source morphemes rather than representing the Japanese versions. Thus, though the Japanese sarariman represents both the $/ 1 /$ and the $/ \mathrm{r} /$ of the English original as $r$ and represents the $/ \mathfrak{x} /$ and the first /o/ as $a$, the Korean copy maintains the English distinctions: ${ }^{20}$

\begin{tabular}{|c|c|}
\hline $\begin{array}{l}\text { poolp'en } \\
\text { shaap'ŭp'ensŭl } \\
\text { saellŏrimaen }\end{array}$ & $\begin{array}{l}\text { *ball-pen } \\
\text { *sharp pencil } \\
\text { *salary-man }\end{array}$ \\
\hline
\end{tabular}

Other examples of wasei eigo that have been carried into Korean include the following. Haikalla is a phonological hybrid. The remainder fully copy English phonology:

$\begin{array}{lllll}\text { Korean } & \text { Japanese } & & & \\ \text { haikalla } & \text { haikarā } & < & \text { *high-collar } & \text { 'swanky' } \\ \text { k'onsent'ŭ } & \text { konsento } & < & \text { ?*oncentric } & \text { 'electric socket' } \\ \text { paekmirŏ } & \text { bakkumirā } & < & \text { *back mirror } & \text { 'rear-view mirror' } \\ \text { sŭt'aendŭ } & \text { sutando } & < & \text { ?*standard } & \text { 'desk lamp' } \\ \text { p'üriiraensŏ } & \text { furīransā } & < & \text { *freelancer } & \text { 'freelance writer' }\end{array}$

Finally, it is worth mentioning that the standard Japanese and Korean 
versions of English blazer are based on a longer form *blazer-coat that does not normally occur in English: burezākōto and pülleijōk'out'ü.

4.3.3. Phonological-semantic hybrids. It is not uncommon for the borrowing between languages to be accompanied by some distinct form of semantic change. So it is that Japanese has changed the meaning of a number of words borrowed from Western languages, particularly in the form of semantic narrowing. Examples from English include

$\begin{array}{ll}\text { furonto } & \text { 'reception desk' }<\text { 'front' } \\ \text { daiya(guramu) } & \text { 'rail timetable' }<\text { 'diagram' }\end{array}$

Two very common examples from among loan-words from other European languages are

abekku 'date' $\quad<$ French avec
arubaito 'student job' $<$ German Arbeit

It is not always easy to distinguish semantic change from truncation. Thus furonto is probably derived from English front desk, although the form *furonto desuku does not normally occur in Japanese.

All four examples above also exist in Korean, partly or wholly copied phonologically from the source European language but with the same meaning that the Japanese forms have, creating phonological-semantic hybrids:

$\begin{array}{ll}\text { p'ŭront'ŭ } & \text { 'reception desk' } \\ \text { taiŏgŭraem } & \text { 'rail timetable' } \\ \text { abek'ŭ } & \text { 'date' } \\ \text { arŭbait'ŭ } & \text { 'student job' }\end{array}$

4.3.4. Phonological-morphological hybrids. A final category of AngloJapanese hybrid loan-words consists of words that are phonologically wholly or partly copied from the English but follow the Japanese model in their treatment of English inflectional endings, particularly the plural morpheme $-s$.

Japanese nouns are generally not marked for number. A few suffixes, particularly -tachi, are used to indicate explicitly either plurality, as in hito-tachi 'people', or collectivity, as in Suzuki-tachi 'Mr. Suzuki and his colleagues/family'. These suffixes are only affixed to animate nouns usually only with human referents - and are never obligatory in the former sense. There is no morphological device for indicating number with inanimate nouns. Consequently, there is some considerable confusion in the cases of English nouns that are mostly or exclusively used in 
the plural as to whether the plural $-s$ should be carried over into the Japanese.

Some nouns that are only used in the plural are copied into Japanese together with the plural $-s:{ }^{21}$

$$
\begin{array}{lll}
\text { surakkusu } & \text { 'slacks' } & \text { (cf. *'slack') } \\
\text { pantsu } & \text { 'pants' } & \text { (cf. *'pant') }
\end{array}
$$

Others are copied without the plural suffix:

(54) sangurasu 'sunglasses' (cf. *'sunglass')

pajama 'pyjamas' (cf. *'pyjama')

Similarly, words that are typically - but not exclusively - used in the plural in English may be copied into Japanese either with the plural ending intact:

$$
\begin{array}{ll}
\text { sokkusu } & \text { 'socks' or 'sock' } \\
\text { kafusu } & \text { 'cuffs' or 'cuff' }
\end{array}
$$

or without the plural ending:

(56) sutokkingu 'stockings' or 'stocking'

surippa 'slippers' or 'slipper'

Regardless of whether the Japanese form retains or loses the plural ending, the same form is used for both singular and plural reference in Japanese.

Korean has also borrowed the English words above, and the Korean forms mostly fully copy the English phonologically. Nevertheless, whether the plural ending is copied into Korean or not shows Japanese influence. Consequently, the English examples above are copied as

(57) Exclusively plural:

$-s$ retained:

sŭllaeksŭ surakkusu 'slacks'

p'aenchŭ pantsu 'pants'

$-s$ lost:

sŏngŭrasŭ ${ }^{22}$ sangurasu 'sunglasses'

\begin{tabular}{|c|c|c|}
\hline soksŭ & sokkusu & 'socks' or 'sock' \\
\hline $\begin{array}{l}\text { k'ŏp'ǔsŭ } \\
\text { lost: }\end{array}$ & kafusu & 'cuffs' or 'cuff' \\
\hline $\begin{array}{l}\text { sŭt'ok'in } \\
\text { sŭllip'ŏ }\end{array}$ & $\begin{array}{l}\text { sutokkingu } \\
\text { surippa }\end{array}$ & $\begin{array}{l}\text { 'stockings' or 'stocking' } \\
\text { 'slippers' or 'slipper' }\end{array}$ \\
\hline
\end{tabular}

p'ajama pajama 'pyjamas'

(58) Typically plural:

$-s$ retained: 
Although it is usually plural $-s$ that is lost in the transfer, sometimes other elements are lost. Consider the following English expressions consisting of two coordinated nouns:

gin and tonic

ham and eggs

Unlike English, both Japanese and Korean can combine two nouns together in a coordinative dvandva compound in cases where there is a high degree of semantic cohesion. ${ }^{23}$ This is a process that is applied to both native elements and Chinese-derived elements:
Japanese Korean
oya-ko ŏrŭn-ai 'parent and child'
te-ashi son-bal 'arms and legs'
fu-bo pu-mo 'father and mother' = Chinese fùmŭ

The cohesion between gin and tonic or between ham and egg, especially as each expression has a single referent rather than two (the gin and the tonic are mixed as one drink, and in the Far East ham and eggs are typically fused together rather than cooked separately), would appear to be responsible for both the Japanese and then the Korean treatment of them as dvandva compounds without the and:
Japanese
Korean
jin-tonikku
chin-t'onik 'gin and tonic'
hamu-eggu
haem-egŭ
'ham and egg(s)'

\section{Loan-words and language purification}

It was mentioned above that Korean has been gradually purged of a great number of Japanese words since the liberation in 1945 (Tanaka and Lee 1986: 128), and the trend has been to replace Japanese-derived forms of English loan-words with forms derived directly from English. Thus sement' $o$ 'cement', taken straight from the Japanese version semento, has been replaced by a form shiment' $\breve{u}$, derived directly from English.

In a great many cases, however, a Japanese form has fallen out of use only after a long struggle. For example, $k$ 'yabare 'cabaret' is another loan-word that was established in its Japanese version during the Japanese occupation. Japanese normally copies English / $\mathrm{kæ} /$ and $/ \mathrm{gæ} /$ not as $k a$ and ga, but as kya and gya (Quackenbush 1977: 161-162). Hence, camp $/ \mathrm{kæmp} /$ and cap / kæp/ enter Japanese as kyampu and kyappu respectively. Korean, on the other hand, does not insert $-y$-, and the Korean equivalents of $/ \mathrm{kæmp} /$ and $/ \mathrm{kæp} /$ are $k^{\prime} a e m p^{\prime} \breve{u}$ and $k^{\prime} a e p$ respectively. Since 
liberation, however, the fully Japanese form $k^{\prime} y a b a r e$ has dropped its $-y$ to give $k^{\prime}$ abare. The resistence on the part of $k^{\prime} y a b a r e$ has been strong. In Lew (1949) it is still $k^{\prime} y a b a r e$ that is listed. Minjungseorim (1972), however, lists only k'abare. Nevertheless, Kim (1977) still lists k'yabare. Pak (1988) naturally prescribes k'abare, and this is the form that has now won.

Consequently, the attempt to purify the language has often resulted in the coexistence of a number of forms in common use. For example, English compass /kımpəs/ occurs both as k'ómp'asŭ (Lew 1949; Pak 1988) and as k'omp'asú (Kim 1977; Minjungseorim 1972, 1980), the former form representing English pronunciation, the latter representing the Japanese version. The Japanese version is spelling-based. ${ }^{24}$

Other words have remained unchallenged. English humour /hju:mə/ is still consistently $y u(u) m o$ from Japanese yūmoa, not *hyuumŏ. Similarly, the truncated forms discussed above continue in common use.

Finally, it is worth noticing that some Japanese features have been so well hidden that they have largely eluded the prescriptivists. In particular, the Japanese misinterpretation of English $/ \mathrm{z} /$ as $/ \mathrm{s} /$ and of $/ \mathrm{s} /$ as $/ \mathbf{z} /$ remains, and English blouse, news, and closeup are listed in Pak (1988) as pŭllausŭ, nyusŭ and $k^{\prime} \breve{u l l o u j u ̆-o ̆ p . ~ I n t e r e s t i n g l y, ~ P a k ~ p r e s c r i b e s ~ a s ~}$

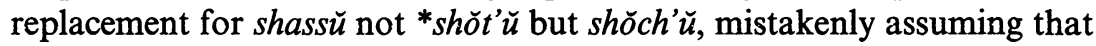
the Japanese source for shassŭ, shatsu was a copy of English shirts. In fact, English syllable-final / $t$ / was copied in the earliest loans consistently as $t s u$ rather than as to, giving baketsu 'bucket' and katsuretsu 'cutlet'.

Received 13 December 1995

Revised version received

University of Sheffield

29 June 1996

\section{Notes}

* I am grateful to three anonymous reviewers from Linguistics for their constructive comments. Any remaining errors are my own. Correspondence address: N. Tranter, School of East Asian Studies, University of Sheffield S10 2TN, Britain.

1. The term "hybrid" is used here differently from Shibatani's (1990: 238) "hybrid compound," which refers to words composed of morphemes from different languages, such as Japanese katorikku-kyo and Korean kat'ollik-kyo 'Catholicism', of which the first element is of Western origin and the second is of Chinese origin.

2. The acceptance of modern Japanese ( $k \bar{g} g o)$ as a vernacular-based written standard, replacing the use of wabun (Classical Japanese) and kanbun (Japanese Chinese) took over half a century (see Twine 1991). Nevertheless, lexical development within the spheres of government, the economy, science, and the military was rapid, and the terms were largely shared by wabun, kanbun, and kögo. The new vocabulary, written as it was 
in Chinese script, provided a model for the rest of Asia. Those responsible for introducing or standardizing technical terminology in China at the same period resorted heavily to existing Japanese forms (see, for example, Cousland 1908: i).

3. A form $p^{\prime} \delta k^{\prime} i t$ is prescribed by Pak (1988), but most dictionaries list only the wellestablished pakkessŭ.

4. It was a frequent practice in Meiji Japan for unfamiliar loan-words to be used together with a Chinese character gloss. The characters would be used in the main text as a visual indication of meaning with the loan-word pronunciation written against it ( furigana). The intention was not that the characters should be read with their Chinesederived pronunciations, although some character combinations have achieved the status of words in their own right (Shibatani 1990: 149-150).

5. Whereas Korean nowadays only uses Chinese characters to represent Chinese-derived morphemes, Japanese uses them also to represent native Japanese words that are similar in meaning to the Chinese morphemes that the characters were created to write. Consequently the characters used for Ōsaka (formed from native Japanese elements meaning 'big slope') can be read in Korean either as Osak' $a$ or with a Chinese-based pronunciation as Taep'an and are read in Chinese as Dàbăn. Occasionally, even common nouns have been borrowed this way, disguising their Japanese origin, such as waribiki 'discount', which has passed into Korean as harin (Tanaka and Lee 1986: 128).

6. I use the terms "copying" and "copy" in the sense of words borrowed from another language (Crowley 1992: 152-153).

7. The main regular exception to this is in the treatment of those vowels that in certain environments are allophones of long-vowel phonemes in Southern varieties of British English (including RP) but are allophones of short vowel phonemes in Northern varieties. For instance, English pass is /pa:s/ in Northern Britain. In such cases, both languages tend to follow the short-vowel version, hence p'aesŭ and pasu, not * $p$ 'aasŭ and ${ }^{*} p \bar{a} s u$.

8. Generally only one geminate is allowed per word, or per element in the case of compound words, when loan-words are copied into Japanese. If the rules were to produce two or more geminates, all but the last are reduced, hence poketto instead of *pokketto.

9. The two product lines in the advertisement for Rok'o Mulsan 'Knocker Products' are eye-catching in the irregularity of their representation of the English. Semi-Line is written in hangŭl as Ssemirain with an ejective initial, whereas Knocker is written not as Nok' $\delta$, as would be expected, but as Rok' $\delta$. This is evocative of the historical change of initial nonpalatal $r$ - to $n$ - that occurred several hundred years ago in most forms of Korean (Martin 1992: 15, 45) and is represented in the current orthography. Most Koreans with names that historically began with $r$ - still romanize them with $r$ - or $l$ Hence former president No T'aeu is normally romanized as Roh Tae-woo.

10. The phenomenon, which is essentially related to whether a Japanese first encounters an English word through the spoken medium or through the written medium, applies not just to the treatment of $/ \partial /$. Some quite extreme forms may occur, such as the copying of the name Penelope /po'neləpi/ of the character Lady Penelope in the animated TV series Thunderbirds as penerōpu, which would be derived from an English pronunciation /'pentloup/, by analogy with röpu/rəup/ and höpu/həup/.

11. The Japanese forms may be copies from German or another European language, but the Korean forms are clearly copied from Japanese originals. Although an origin from another European language might explain the choice of vowels, it would not explain the use of Korean -yum or other features. For instance, German originals would have been expected to give the Japanese form *katomiumu rather than kadomiumu, which is the source for the Korean copy. 
12. Many underlying word-final and three-consonant word-medial clusters exist, but these are reduced on the surface (Sohn 1994: 441, 476-478). For example, the base form $/ \mathrm{kaps} /$ 'price' is reduced in isolation and before a consonant to $/ \mathrm{kap} /$, and the $/ \mathrm{s} /$ only resurfaces before a vowel-initial suffix, in which case the $/ \mathrm{p} /$ and the $/ \mathrm{s} /$ belong to different syllables.

13. In China and Korea, such bimorphemic compounds are disyllabic, as each Chinese morpheme is one syllable in length. In Japan, assimilation of such morphemes to the strict mora structure of Japanese has resulted in a great many of the morphemes consisting of two morae. Thus, corresponding to Chinese guó, Cantonese gwok, and Korean $k u k$ 'country', Japanese has koku.

14. Truncation is a widely used device in Japanese, applied particularly to Sino-Japanese forms. For example, kokusai rengo 'United Nations' (lit. 'International League') is more commonly referred to in both speech and writing as kokuren, truncating both elements within the compound, and Korean similarly has both kukche (r) yornhap and truncated kunnyon for the same word. Sometimes compounds of native Japanese and Sino-Japanese elements are abbreviated, hence gakusei waribiki 'student discount' is commonly reduced to gakuwari. Even some Western loan-words are doubly truncated, such as $w \bar{a}(d o)$ puro( $\operatorname{sess} \bar{a})$.

15. Autobike is itself not an English formation but falls under the heading of wasei eigo in section 4.3.2.

16. Kuranku and demo are probably not derived directly from English. The short vowel $o$ in demo suggests an original schwa and hence also truncation as the origin. See the comments concerning puro/p'üro. Puropōzu could also be derived from the English verb as puropōzu suru 'to propose' (the suru 'do' is a necessary auxiliary to loan-verbs in order to carry the inflections), and puropōzu 'proposal' is a back-formation from it. Compare with sain 'signature/autograph', which is back-formed from sain suru 'to sign'.

17. As mentioned above, phonemic length tends not to be realized in native Korean words and loan-words into Korean alike, and this is now generally represented in the orthography. Thus, $/ 0: /$ and $/ \partial v /$ merge in Korean as $o$. It must be remembered, however, that this merger is due to changes within the phonology of Korean and not due to borrowing via Japanese. Moreover, two equivalents to Japanese puropōzu exist in Korean. The one, p'úrop'oojü/p'ürop'ojŭ, as listed in Minjungseorim (1972, 1980), is wholly borrowed from Japanese, with the nondiphthongal representation of /ov/ and the reinterpretation of schwa as a stressed vowel based on the spelling of the English. P'ürop'oujü, on the other hand, is the form prescribed by Pak (1988), as well as in Kim's (1977) vocabulary of Korean for Japanese speakers.

18. Japanese does also have the form sutoraiku, which represents the baseball term strike. Sutoraiki, on the other hand, refers to strike in the sense of industrial action.

19. Although it is possible that ero and p'urro have been truncated within Korean rather than having been borrowed in truncated form from Japanese, the latter is the most likely origin. Note that it is the short forms, and not the longer forms, that exist in Korean, suggesting that the words were borrowed short.

20. Korean represents English /mən/ consistently as maen, as in saellorimaen and seiljŭmaen, because each element in an English compound word is treated independently when copied into Korean.

21. The English will only drop the $-s$ in composition: hence pyjama-case, although *pyjama does not occur as an independent form.

22. Sŏngŭrasŭ is a hybrid in Shibatani's sense (see note 1 above). The sŏn is directly from English, the gŭrasŭ directly from Japanese. 
23. Kageyama (1982: 235) points out that coordinative combinations without intervening particles can occur even at the phrasal level: e.g. inu, saru, kiji 'a dog, a monkey, and a pheasant'.

24. An earlier, pronunciation-based version in Japanese produced the Korean form $k^{\prime} a m p ' a s u \check{~ a s ~ r e c o r d e d ~ b y ~ U n d e r w o o d ~ a n d ~ U n d e r w o o d ~(1925) . ~ B o t h ~ t h e ~ K o r e a n ~ a n d ~}$ Japanese forms are now obsolete. It is worth noting that the transcription principles established by the Chosonno Hakhoe during the Japanese occupation (1940b: 9) prescribe $a$ for English $/ \Lambda /$, rather than the $\check{o}$ that has become standard since liberation.

\section{References}

Chosŏnŏ Hakhoe (1940a). Hangŭl Matchumbŏp T'opiran [Proposals for Unifying Hangŭl Orthography]. Seoul: Chosonno Hakhoe.

-(1940b). Oeraeŏ P'yogibŏp T'oniran [Proposals for Unifying the Representation of LoanWords]. Seoul: Chosǒnǒ Hakhoe.

Cousland, Philip B. (1908). An English-Chinese Lexicon of Medical Terms Compiled for the Terminology Committee. Shanghai: Medical Missionary Association of China.

Crowley, Terry (1992). An Introduction to Historical Linguistics, 2nd ed. Auckland, etc.: Oxford University Press.

Eccardt, Thomas; and Oh Wonchul (1993), Hippocrene Handy Dictionaries: Korean. New York: Hippocrene.

Haarmann, Harald (1986). Verbal strategies in Japanese fashion magazines - a study in impersonal bilingualism and ethnosymbolism. International Journal of the Sociology of Language 58, 107-121.

Hannas, William Carl (1994). The Simplification of Chinese Character-Based Writing. Ann Arbor: University Microfilms International.

Hinds, John V. (1974). Make mine burakku. Ǒhak Yðngu 10, 92-108.

Honna, Nobuyuki (1995). English in Japanese society: language within language. Journal of Multilingual and Multicultural Development 16: Multilingual Japan, 45-62.

Kageyama, Taro (1982). Word formation in Japanese. Lingua 57, 215-258.

Kim, Ch'ung-shik (1977). Kankokugo Bunrui Tangoshū [Korean Classified Vocabulary]. Tokyo: Daigaku Shorin.

Kim, Jin-p'yŏng (1983). The letterforms of han'gül: its origin and process of transformation. In The Korean Language, UNESCO (ed.), 80-102. Seoul and Oregon: Si-sa-yong-o-sa and Pace International Research.

Kim, Talgo (1988). Parŭn Malp'yŏnnam [Manual of Correct Language]. Seoul: Kyðng'un Ch'ulp'ansa.

Kokuritsu Kokugo Kenkyūjo (1990). Gairaigo no Keisei to sono Kyõiku [The Formation of Loan-Words and the Teaching of Them]. Tokyo: Kokuritsu Kokugo Kenkyüjo.

Lee, Hansol Hyun-bok (1989). Korean Grammar. Oxford: Oxford University Press.

Lew, Hyungki J. (1949). New Life English-Korean Dictionary. Seoul: New Life Press.

Liu, Yongquan (1986). Terminological development and organization in China. International Journal of the Sociology of Language 59, 33-46.

Lovins, Julie B. (1975). Loanwords and the Phonological Structure of Japanese. Bloomington: Indiana University Linguistics Club.

Lukoff, Fred (1982). An Introductory Course in Korean. Seoul: Yonsei University Press.

Martin, Samuel E. (1992). A Reference Grammar of Korean: A Complete Guide to the Grammar and History of the Korean Language. Rutland, VT, and Tokyo: Tuttle. 
-; and Lee, Young-Sook C. (1969). Beginning Korean. New Haven and London: Yale University Press.

McCawley, James D. (1968). The Phonological Component of a Grammar of Japanese. The Hague and Paris: Mouton.

Mackerras, Colin (1992). Eastern Asia: An Introductory History. Melbourne: Longman Cheshire.

Miller, Roy Andrew (1967). The Japanese Language. Chicago and London: University of Chicago Press.

Minjungseorim (1972). Essence Korean-English Dictionary. Seoul: Minjungseorim.

-(1980). Essence English-Korean Dictionary, 2nd ed. Seoul: Minjungseorim.

Pak, Kapch'ŏn (1988). Sae Hangŭl Match'umbŏp Sajŏn [New Dictionary of Hangŭl Orthography]. Seoul: Chiphyŏnjŏn.

Pak, Kapsu (1984). Kugö-ŭi P'yonyoon-gwa Sunhwa [Expression and Purification of the Korean Language]. Seoul: Chihaksa.

Park, Jeong-Woon (1994). Variation of vowel length in Korean. In Theoretical Issues in Korean Linguistics, Young-Key Kim-Renaud (ed.), 175-187. Stanford: Leland Stanford Junior University CSLI Publications.

Quackenbush, Hiroko C. (1977). English loanwords in Japanese: why are they difficult for English-speaking students? Journal of the Association of Teachers of Japanese 12, 149-173.

Shibatani, Masayoshi (1990). The Languages of Japan. Cambridge: Cambridge University Press.

Sohn, Ho-Min (1994). Korean. London and New York: Routledge.

Tanaka, Katsuhiko; and Lee, Yeonsuk (1986). Aspekte der japanisch-koreanischen Sprachkontakte und Lehnbeziehungen [Aspects of Japanese-Korean language contact and borrowing]. International Journal of the Sociology of Language 58, 123-128.

Twine, Nanette (1991). Language and the Modern State: The Reform of Written Japanese. London and New York: Routledge.

Underwood, Horace Grant; and Underwood, Horace Horton (1925). An English-Korean Dictionary. Seoul: YMCA Printing Department.

Vance, Timothy J. (1986). An Introduction to Japanese Phonology. Albany: State University of New York Press.

Vandesande, Anthony V. (1968). Myŏngdo's Korean. Seoul: Myŏngdo Institute. 


$\begin{array}{ll}\text { k'omyunik'eishŏn } & \text { 'communication' } \\ \text { k'omediŏn } & \text { 'comedian' } \\ \text { k'omp'yut'ǒ } & \text { 'computer' } \\ \text { k'omp'ŭresŏ } & \text { 'compressor' }\end{array}$

In some cases, however, a form containing $k^{\prime}$ ŏm- (or $k^{\prime} \breve{o n}^{\prime}$ ) occurs:

(34) k'ŏmishŏn 'commission'

k'ŏndishŏn . 'condition'

The second reason is that the spelling-based copy is due to Japanese influence. When two schwas are present in the English, both are very frequently reinterpreted as though they were stressed. Common examples include

$\begin{array}{llll}\text { Korean } & \text { Japanese } & & \\ \text { k'amera } & \text { kamera } & \text { /kæmərə/ } & \text { 'camera' } \\ \text { korilla } & \text { gorira } & \text { /gərılə/ } & \text { 'gorilla' }\end{array}$

Note that although the Korean forms are mostly copies from Japanese, the distinction between $/ \mathrm{r} /$ and $/ 1 /$ in English, neutralized in the Japanese forms as $r$, is reinstated in Korean. As mentioned earlier, native Japanese words normally contain short vowels only, and so kamera and gorira fit the native pattern. As a result, there are many examples of English words that contain not just a schwa but a long vowel that are reinterpreted with stressed spelling-based short vowels throughout. Generally these words are carried over into Korean with the same vowels as in English:

$\begin{array}{ll}\text { (36) k'amelleon } & \begin{array}{l}\text { kamereon 'chameleon' } \\ \text { pija }\end{array} \text { biza } \\ \end{array}$

There are other examples of English long vowels or diphthongs being shortened in Japanese. In many of these, the vowels of two syllables occur in succession without an intervening consonant, such as /ouetsis/ oasis or $/ \mathrm{ni}: \mathrm{pn} /$ neon. The sequence of two long vowels (or four vowel morae) that a form ${ }^{*} \bar{o} \bar{e}$ shisu would have is contrary to the ideal CVCV structure of Japanese, and there are only a few words in common usage in Japanese with two long vowels, such as $h \bar{o} \bar{o}$ 'pope'. Again, Korean normally copies the Japanese vowels throughout:

$$
\begin{array}{lll}
\text { oashisŭ } & \text { oashisu 'oasis' } \\
\text { neon } & \text { neon } & \text { 'neon' }
\end{array}
$$

4.2.2. Kana-based. There are a number of cases of English loan-words in Japanese that contain unusual copies of an English vowel. In many cases, the unusual vowels are copied into Korean. Examples include 
(38)

$\begin{array}{llll}\text { t'ǒŏbin } & \text { tãbin } & \text { /t3:bain/ } & \text { 'turbine' } \\ \text { pui } & \text { bui } & \text { /bol/ } & \text { 'buoy' } \\ \text { mishin } & \text { mishin } & \text { /məSi:n/ } & \text { '(sewing) machine' } \\ \text { orenji } & \text { orenji } & \text { /orund3/ } & \text { 'orange' } \\ \text { k'akt'eil } & \text { kakutēru } & \text { /knktell/ } & \text { 'cocktail' }\end{array}$

Of these, the copies of turbine, buoy, and cocktail suggest an American English origin, while the other forms are difficult to explain. A German or French origin for $t^{\prime}$ ŏobin/täbin might explain the choice of the second vowel, but the first vowel $\check{o} \check{o} / \bar{a}$ can only be copied from English.

One final case is that of the Latin-derived suffix -ium. The suffix is pronounced either as $/ \mathrm{r} ə \mathrm{~m} /$ in all cases or as $/ \mathrm{j} ə \mathrm{~m} /$, although the latter pronunciation does not occur if the combination is preceded by a consonant cluster. Hence, uranium is pronounced /joreınıəm/ or /jureinjəm/, but cadmium is pronounced only as / $\mathrm{kædm}$ təm/. The Japanese copies of these words are distinctively spelling-based throughout, producing uraniumu (rather than *yurēniumu) and kadomiumu. In practice, however, the combination $i u$ is alien to Japanese, and words that historically contained the combination have changed to $y \bar{u}$, and the same change has been applied to -iumu in pronunciation, even in such cases as kadomiumu:

$\begin{array}{llll}\text { arumi(niumu) } & \text { pronounced } & \text { arumi(nyūmu) } & \text { 'aluminium' } \\ \text { uraniumu } & \text { pronounced } & \text { uranyūmu } & \text { 'uranium' } \\ \text { maguneshiumu } & \text { pronounced } & \text { maguneshūmu } & \text { 'magnesium' } \\ \text { kadomiumu } & \text { pronounced } & \text { kadomyūmu } & \text { 'cadmium' } \\ \text { puranetariumu } & \text { pronounced } & \text { puranetaryūmu } & \text { 'planetarium' } \\ \text { zeraniumu } & \text { pronounced } & \text { zeranyūmu } & \text { 'geranium' }\end{array}$

Korean has copied the vowels of the Japanese forms throughout. Not only are the vowels in English uranium copied according to the Japanese version as $u$ and $a$ rather than after the English pronunciation as $y u$ and $e i$, the / $/ 2 m /$ is copied as -yum and not as -iüm, as would be expected (compare $p$ 'ürijüm for English prism): ${ }^{11}$

(40)

$\begin{array}{ll}\text { alluminyum } & \text { 'aluminium' } \\ \text { uranyum } & \text { 'uranium' } \\ \text { magŭneshum } & \text { 'magnesium' } \\ \text { k'adŭmyum } & \text { 'cadmium' } \\ \text { cheranetlaryum } & \text { 'planetarium' }\end{array}$

\subsection{Japanese word-formation processes}

The Anglo-Japanese loans discussed above have been borrowed neither directly from English nor fully via Japanese but rather contain character- 
istics that are typical of both languages. A final major category of hybrid loans consists of words of which many are fully derived from English in terms of their phonemic representation - although others may also be phonetically hybrid - but which display Japanese word-formative processes. The two main varieties are truncated loans and lexemes known in Japan as wasei eigo 'made-in-Japan English'.

4.3.1. Truncation. The typical native Japanese noun has a two-syllable CVCV structure, although there are several CV and CVCVCV nouns, and therefore compounds typically have a four-syllable CVCV-CVCV structure. The only consonant clusters allowed are word-medial twoconsonant clusters of which the first element is the syllabic nasal $n$, which phonetically is homorganic with the following consonant. Native Korean nouns exhibit a wider variety of patterns, although the vast majority of nouns typically consist of between one and three syllables, and although Korean allows many more clusters than Japanese, it is still comparatively poor in the number of clusters that are allowed, and word-initial clusters, word-final clusters, and three-consonant clusters are disallowed. ${ }^{12}$ The Chinese loan-words in both languages, or words created in Japan or Korea from Chinese morphemes, are largely bimorphemic. ${ }^{13}$

The general Japanese and Korean tendency for nouns to consist of between one and three syllables with limited possibilities for consonant clustering has been disrupted by the great influx of western loan-words into the languages. Large numbers of extremely long and awkward loanwords have emerged through the regular use of epenthetic vowels to break up unacceptable consonant clusters and of paragogic vowels to avoid final consonants. Thus the monosyllabic strike is represented in both Japanese and Korean as five morae:
Japanese: su-to-ra-i-ki
Korean: sŭ-t'ŭ-ra-i-k'ŭ

The Japanese response to this has to be to truncate many such unwieldly words to a more acceptable Japanese structure. ${ }^{14}$ For example, the English words below would be expected to give the Japanese reflexes listed to their right:

\begin{tabular}{|c|c|c|}
\hline $\begin{array}{l}\text { 'sion' } \\
\text { bike'15 } \\
\text { ' } \\
\text { 'nstration' } \\
\text { ion' }\end{array}$ & 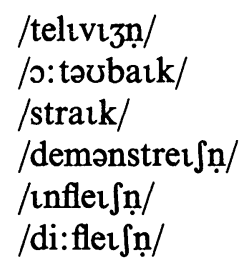 & $\begin{array}{l}\text { terebijon } \\
\text { *ōtobaiki } \\
\text { sutoraiki } \\
\text { demonsutorēsh } \\
\text { infurēshon } \\
\text { defurēshon }\end{array}$ \\
\hline
\end{tabular}




$\begin{array}{lll}\text { 'proposal' } & \text { /prə/ppəozl/ } & \text { *puropōzaru } \\ \text { 'crankshaft' } & / \text { kræykjæft/ } & \text { *kurankushafuto }\end{array}$

Although some of these do exist, others are not normally found in Japanese in their full form. Rather, truncated forms for all are more common in the spoken language: ${ }^{16}$

$\begin{array}{ll}\text { terebijon } & \Rightarrow \text { terebi } \\ \text { *ōtobaiki } & \Rightarrow \text { otobai } \\ \text { sutoraiki } & \Rightarrow \text { suto } \\ \text { demonsutorēshon } & \Rightarrow \text { demo } \\ \text { infurēshon } & \Rightarrow \text { infure } \\ \text { defurēshon } & \Rightarrow \text { defure } \\ \text { *puropōzaru } & \Rightarrow \text { puropōzu } \\ \text { *kurankushafuto } & \Rightarrow \text { kuranku }\end{array}$

The common Korean reflexes for the same English words often also show the same truncation, giving

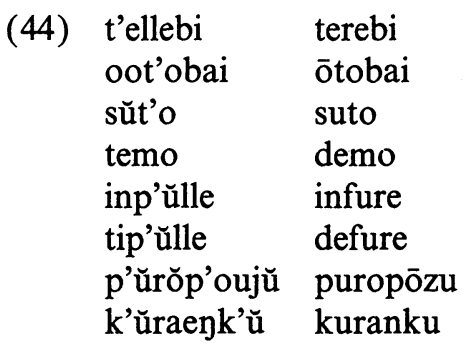

The truncation is clearly influenced by Japanese. However, in most cases the phonology of the words is English-based. Thus, the English distinctions of / $/ 0: /$ vs. /ov/ represented in *autobike and proposal above are maintained in Korean as $o o$ and $o u$ when vowel length is indicated, even though in Japanese the vowels are obligatorily merged as $\bar{o} .^{17}$ Similarly, the distinction between English $/ 1 /$, as in inflation, and / $r /$, as in crank, is neutralized in the Japanese representations but is maintained in Korean in accordance with the English-Korean correspondence rules. Again, however, both patterns for the treatment of unstressed vowels are represented: the unstressed vowels represented in tip'ülle and p'ürŏp'oujŭ are based on the sound of the English (as opposed to Japanese defure and puropōzu), whereas those in t'ellebi and oot'obai are based on the spelling of the English (through the influence of Japanese).

Full forms of some of the above, such as inp'ülleishŏn, tip'ülleishŏn and especially t'ellebijorn are also found in Korean, whereas the full forms of temo or oot'obai are either very uncommon or do not exist. Note that 
the full form from English strike would have developed as *süt'oraik'i if it had been borrowed in its Japanese form. The form that actually occurs in Korean is süt'üraik' $\breve{u}$ with the regular epenthetic/paragogic vowel $\breve{u}$ throughout, showing no influence from Japanese. ${ }^{18}$ Nevertheless, the truncated form is not ${ }^{*}$ sŭt' $\breve{u}$, which might be expected if the truncation had occurred within Korean, but sŭt'o, preserving the $o$ as the regular Japanese epenthetic/paragogic vowel after $t$ or $d$.

The following three very common loan-words in Korean phonologically fully copy the English original and yet are truncated through the influence of the Japanese version.

$\begin{array}{lll}\text { Korean } & \text { Japanese } & \text { English } \\ \text { ap'aat'ŭ } & \text { apāto } & \text { 'apart(ment)' } \\ \text { oubǒ } & \overline{o b a ̄ a} & \text { 'over(coat)' } \\ \text { p'ǒŏmŏ } & \text { pāma } & \text { 'perma(nent wave)' }\end{array}$

Although the morphemes apart and over occur in English, they are not used as truncations for apartment or overcoat respectively. Permanent wave in English is commonly abbreviated to perm, but an English form *perma, which underlies both the Japanese and the Korean versions, does not occur.

Some truncated loans, however, fully copy Japanese in both their phonology and their truncation: ${ }^{19}$

$\begin{array}{lll}\text { ero } & \text { ero } & \text { 'ero(ticism)' } \\ \text { nega } & \text { nega } & \text { 'nega(tive)' } \\ \text { k'ombi } & \text { konbi } & \text { 'combi(nation)' } \\ \text { p'ŭro } & \text { puro } & \text { 'pro(fessional/letariat/gram)' } \\ \text { taia } & \text { daiya } & \text { 'dia(gram/mond)' }\end{array}$

Of these, p'üro and taia are worthy of comment. The phonology of p'üro suggests that it has entered Korean from Japanese puro, since derivation from the English truncated form pro /pros/ would give the nonexistent form * ${ }^{*}$ 'urou in the same way that show / Jəu/ has given shou. $P$ 'uro is given by the Essence dictionaries as an abbreviation of three different words in English: professional, proletariat, and program. Of these, only the first exists in a truncated form in English. Japanese, however, frequently abbreviates all three as puro, as well as four other words (see Miller 1967).

The case of taia is similar to that of süt'o mentioned above, in that its truncated form is copied from the Japanese with a spelling-based $a$ representing English schwa. However, the full Korean version for diagram, taiŏgŭraem (= Japanese daiyaguramu), regularly copies the English throughout and represents the English schwa with $\breve{o}$. The full version is 
nevertheless a hybrid loan for reasons explained in section 4.3.3 below. The full version for diamond, taiamond $\breve{u}$ (= Japanese daiyamondo), retains the Japanese-influenced representation of two English schwas but does not display Japanese influence in the representation of the final /d/ of the English.

4.3.2. Wasei eigo. It was mentioned in section 2.3 that Japanese has made extensive use of bound Chinese-derived morphemes to create new words that do not exist in Chinese. The tradition has also been, extended to English-derived morphemes. There are a number of very common compound words in Japanese that are made from combining English elements that are not found together in English. An example is that of Japanese ótobai and Korean oot'obai 'motorbike' above, derived from combining auto- with bi(ke) in English, although *autobike is not found in English. This kind of English word is known as wasei eigo, 'made-inJapan English'. Other examples are

$\begin{array}{lll}\text { bōrupen } & \text { *ball-pen } & \text { 'ball-point pen, biro' } \\ \text { shāpupenshiru } & \text { *sharp pencil } & \text { 'propelling pencil' } \\ \text { sararīman } & \text { *salary-man } & \text { 'white-collar worker' }\end{array}$

Although the words do not exist in English, Korean has borrowed them from Japanese. As is usual among hybrid loans, the vowels and the $/ 1 /: / r /$ distinction in the Korean versions reflect fully the English source morphemes rather than representing the Japanese versions. Thus, though the Japanese sarariman represents both the $/ 1 /$ and the $/ \mathrm{r} /$ of the English original as $r$ and represents the $/ \mathfrak{x} /$ and the first /o/ as $a$, the Korean copy maintains the English distinctions: ${ }^{20}$

\begin{tabular}{|c|c|}
\hline $\begin{array}{l}\text { poolp'en } \\
\text { shaap'ŭp'ensŭl } \\
\text { saellŏrimaen }\end{array}$ & $\begin{array}{l}\text { *ball-pen } \\
\text { *sharp pencil } \\
\text { *salary-man }\end{array}$ \\
\hline
\end{tabular}

Other examples of wasei eigo that have been carried into Korean include the following. Haikalla is a phonological hybrid. The remainder fully copy English phonology:

$\begin{array}{lllll}\text { Korean } & \text { Japanese } & & & \\ \text { haikalla } & \text { haikarā } & < & \text { *high-collar } & \text { 'swanky' } \\ \text { k'onsent'ŭ } & \text { konsento } & < & \text { ?*oncentric } & \text { 'electric socket' } \\ \text { paekmirŏ } & \text { bakkumirā } & < & \text { *back mirror } & \text { 'rear-view mirror' } \\ \text { sŭt'aendŭ } & \text { sutando } & < & \text { ?*standard } & \text { 'desk lamp' } \\ \text { p'üriiraensŏ } & \text { furīransā } & < & \text { *freelancer } & \text { 'freelance writer' }\end{array}$

Finally, it is worth mentioning that the standard Japanese and Korean 
versions of English blazer are based on a longer form *blazer-coat that does not normally occur in English: burezākōto and pülleijōk'out'ü.

4.3.3. Phonological-semantic hybrids. It is not uncommon for the borrowing between languages to be accompanied by some distinct form of semantic change. So it is that Japanese has changed the meaning of a number of words borrowed from Western languages, particularly in the form of semantic narrowing. Examples from English include

$\begin{array}{ll}\text { furonto } & \text { 'reception desk' }<\text { 'front' } \\ \text { daiya(guramu) } & \text { 'rail timetable' }<\text { 'diagram' }\end{array}$

Two very common examples from among loan-words from other European languages are

abekku 'date' $\quad<$ French avec
arubaito 'student job' $<$ German Arbeit

It is not always easy to distinguish semantic change from truncation. Thus furonto is probably derived from English front desk, although the form *furonto desuku does not normally occur in Japanese.

All four examples above also exist in Korean, partly or wholly copied phonologically from the source European language but with the same meaning that the Japanese forms have, creating phonological-semantic hybrids:

$\begin{array}{ll}\text { p'ŭront'ŭ } & \text { 'reception desk' } \\ \text { taiŏgŭraem } & \text { 'rail timetable' } \\ \text { abek'ŭ } & \text { 'date' } \\ \text { arŭbait'ŭ } & \text { 'student job' }\end{array}$

4.3.4. Phonological-morphological hybrids. A final category of AngloJapanese hybrid loan-words consists of words that are phonologically wholly or partly copied from the English but follow the Japanese model in their treatment of English inflectional endings, particularly the plural morpheme $-s$.

Japanese nouns are generally not marked for number. A few suffixes, particularly -tachi, are used to indicate explicitly either plurality, as in hito-tachi 'people', or collectivity, as in Suzuki-tachi 'Mr. Suzuki and his colleagues/family'. These suffixes are only affixed to animate nouns usually only with human referents - and are never obligatory in the former sense. There is no morphological device for indicating number with inanimate nouns. Consequently, there is some considerable confusion in the cases of English nouns that are mostly or exclusively used in 
the plural as to whether the plural $-s$ should be carried over into the Japanese.

Some nouns that are only used in the plural are copied into Japanese together with the plural $-s:{ }^{21}$

$$
\begin{array}{lll}
\text { surakkusu } & \text { 'slacks' } & \text { (cf. *'slack') } \\
\text { pantsu } & \text { 'pants' } & \text { (cf. *'pant') }
\end{array}
$$

Others are copied without the plural suffix:

(54) sangurasu 'sunglasses' (cf. *'sunglass')

pajama 'pyjamas' (cf. *'pyjama')

Similarly, words that are typically - but not exclusively - used in the plural in English may be copied into Japanese either with the plural ending intact:

$$
\begin{array}{ll}
\text { sokkusu } & \text { 'socks' or 'sock' } \\
\text { kafusu } & \text { 'cuffs' or 'cuff' }
\end{array}
$$

or without the plural ending:

(56) sutokkingu 'stockings' or 'stocking'

surippa 'slippers' or 'slipper'

Regardless of whether the Japanese form retains or loses the plural ending, the same form is used for both singular and plural reference in Japanese.

Korean has also borrowed the English words above, and the Korean forms mostly fully copy the English phonologically. Nevertheless, whether the plural ending is copied into Korean or not shows Japanese influence. Consequently, the English examples above are copied as

(57) Exclusively plural:

$-s$ retained:

sŭllaeksŭ surakkusu 'slacks'

p'aenchŭ pantsu 'pants'

$-s$ lost:

sŏngŭrasŭ ${ }^{22}$ sangurasu 'sunglasses'

\begin{tabular}{|c|c|c|}
\hline soksŭ & sokkusu & 'socks' or 'sock' \\
\hline $\begin{array}{l}\text { k'ŏp'ǔsŭ } \\
\text { lost: }\end{array}$ & kafusu & 'cuffs' or 'cuff' \\
\hline $\begin{array}{l}\text { sŭt'ok'in } \\
\text { sŭllip'ŏ }\end{array}$ & $\begin{array}{l}\text { sutokkingu } \\
\text { surippa }\end{array}$ & $\begin{array}{l}\text { 'stockings' or 'stocking' } \\
\text { 'slippers' or 'slipper' }\end{array}$ \\
\hline
\end{tabular}

p'ajama pajama 'pyjamas'

(58) Typically plural:

$-s$ retained: 
Although it is usually plural $-s$ that is lost in the transfer, sometimes other elements are lost. Consider the following English expressions consisting of two coordinated nouns:

gin and tonic

ham and eggs

Unlike English, both Japanese and Korean can combine two nouns together in a coordinative dvandva compound in cases where there is a high degree of semantic cohesion. ${ }^{23}$ This is a process that is applied to both native elements and Chinese-derived elements:
Japanese Korean
oya-ko ŏrŭn-ai 'parent and child'
te-ashi son-bal 'arms and legs'
fu-bo pu-mo 'father and mother' = Chinese fùmŭ

The cohesion between gin and tonic or between ham and egg, especially as each expression has a single referent rather than two (the gin and the tonic are mixed as one drink, and in the Far East ham and eggs are typically fused together rather than cooked separately), would appear to be responsible for both the Japanese and then the Korean treatment of them as dvandva compounds without the and:
Japanese
Korean
jin-tonikku
chin-t'onik 'gin and tonic'
hamu-eggu
haem-egŭ
'ham and egg(s)'

\section{Loan-words and language purification}

It was mentioned above that Korean has been gradually purged of a great number of Japanese words since the liberation in 1945 (Tanaka and Lee 1986: 128), and the trend has been to replace Japanese-derived forms of English loan-words with forms derived directly from English. Thus sement' $o$ 'cement', taken straight from the Japanese version semento, has been replaced by a form shiment' $\breve{u}$, derived directly from English.

In a great many cases, however, a Japanese form has fallen out of use only after a long struggle. For example, $k$ 'yabare 'cabaret' is another loan-word that was established in its Japanese version during the Japanese occupation. Japanese normally copies English / $\mathrm{kæ} /$ and $/ \mathrm{gæ} /$ not as $k a$ and ga, but as kya and gya (Quackenbush 1977: 161-162). Hence, camp $/ \mathrm{kæmp} /$ and cap / kæp/ enter Japanese as kyampu and kyappu respectively. Korean, on the other hand, does not insert $-y$-, and the Korean equivalents of $/ \mathrm{kæmp} /$ and $/ \mathrm{kæp} /$ are $k^{\prime} a e m p^{\prime} \breve{u}$ and $k^{\prime} a e p$ respectively. Since 
liberation, however, the fully Japanese form $k^{\prime} y a b a r e$ has dropped its $-y$ to give $k^{\prime}$ abare. The resistence on the part of $k^{\prime} y a b a r e$ has been strong. In Lew (1949) it is still $k^{\prime} y a b a r e$ that is listed. Minjungseorim (1972), however, lists only k'abare. Nevertheless, Kim (1977) still lists k'yabare. Pak (1988) naturally prescribes k'abare, and this is the form that has now won.

Consequently, the attempt to purify the language has often resulted in the coexistence of a number of forms in common use. For example, English compass /kımpəs/ occurs both as k'ómp'asŭ (Lew 1949; Pak 1988) and as k'omp'asú (Kim 1977; Minjungseorim 1972, 1980), the former form representing English pronunciation, the latter representing the Japanese version. The Japanese version is spelling-based. ${ }^{24}$

Other words have remained unchallenged. English humour /hju:mə/ is still consistently $y u(u) m o$ from Japanese yūmoa, not *hyuumŏ. Similarly, the truncated forms discussed above continue in common use.

Finally, it is worth noticing that some Japanese features have been so well hidden that they have largely eluded the prescriptivists. In particular, the Japanese misinterpretation of English $/ \mathrm{z} /$ as $/ \mathrm{s} /$ and of $/ \mathrm{s} /$ as $/ \mathbf{z} /$ remains, and English blouse, news, and closeup are listed in Pak (1988) as pŭllausŭ, nyusŭ and $k^{\prime} \breve{u l l o u j u ̆-o ̆ p . ~ I n t e r e s t i n g l y, ~ P a k ~ p r e s c r i b e s ~ a s ~}$

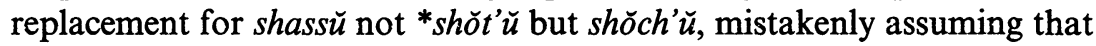
the Japanese source for shassŭ, shatsu was a copy of English shirts. In fact, English syllable-final / $t$ / was copied in the earliest loans consistently as $t s u$ rather than as to, giving baketsu 'bucket' and katsuretsu 'cutlet'.

Received 13 December 1995

Revised version received

University of Sheffield

29 June 1996

\section{Notes}

* I am grateful to three anonymous reviewers from Linguistics for their constructive comments. Any remaining errors are my own. Correspondence address: N. Tranter, School of East Asian Studies, University of Sheffield S10 2TN, Britain.

1. The term "hybrid" is used here differently from Shibatani's (1990: 238) "hybrid compound," which refers to words composed of morphemes from different languages, such as Japanese katorikku-kyo and Korean kat'ollik-kyo 'Catholicism', of which the first element is of Western origin and the second is of Chinese origin.

2. The acceptance of modern Japanese ( $k \bar{g} g o)$ as a vernacular-based written standard, replacing the use of wabun (Classical Japanese) and kanbun (Japanese Chinese) took over half a century (see Twine 1991). Nevertheless, lexical development within the spheres of government, the economy, science, and the military was rapid, and the terms were largely shared by wabun, kanbun, and kögo. The new vocabulary, written as it was 
in Chinese script, provided a model for the rest of Asia. Those responsible for introducing or standardizing technical terminology in China at the same period resorted heavily to existing Japanese forms (see, for example, Cousland 1908: i).

3. A form $p^{\prime} \delta k^{\prime} i t$ is prescribed by Pak (1988), but most dictionaries list only the wellestablished pakkessŭ.

4. It was a frequent practice in Meiji Japan for unfamiliar loan-words to be used together with a Chinese character gloss. The characters would be used in the main text as a visual indication of meaning with the loan-word pronunciation written against it ( furigana). The intention was not that the characters should be read with their Chinesederived pronunciations, although some character combinations have achieved the status of words in their own right (Shibatani 1990: 149-150).

5. Whereas Korean nowadays only uses Chinese characters to represent Chinese-derived morphemes, Japanese uses them also to represent native Japanese words that are similar in meaning to the Chinese morphemes that the characters were created to write. Consequently the characters used for Ōsaka (formed from native Japanese elements meaning 'big slope') can be read in Korean either as Osak' $a$ or with a Chinese-based pronunciation as Taep'an and are read in Chinese as Dàbăn. Occasionally, even common nouns have been borrowed this way, disguising their Japanese origin, such as waribiki 'discount', which has passed into Korean as harin (Tanaka and Lee 1986: 128).

6. I use the terms "copying" and "copy" in the sense of words borrowed from another language (Crowley 1992: 152-153).

7. The main regular exception to this is in the treatment of those vowels that in certain environments are allophones of long-vowel phonemes in Southern varieties of British English (including RP) but are allophones of short vowel phonemes in Northern varieties. For instance, English pass is /pa:s/ in Northern Britain. In such cases, both languages tend to follow the short-vowel version, hence p'aesŭ and pasu, not * $p$ 'aasŭ and ${ }^{*} p \bar{a} s u$.

8. Generally only one geminate is allowed per word, or per element in the case of compound words, when loan-words are copied into Japanese. If the rules were to produce two or more geminates, all but the last are reduced, hence poketto instead of *pokketto.

9. The two product lines in the advertisement for Rok'o Mulsan 'Knocker Products' are eye-catching in the irregularity of their representation of the English. Semi-Line is written in hangŭl as Ssemirain with an ejective initial, whereas Knocker is written not as Nok' $\delta$, as would be expected, but as Rok' $\delta$. This is evocative of the historical change of initial nonpalatal $r$ - to $n$ - that occurred several hundred years ago in most forms of Korean (Martin 1992: 15, 45) and is represented in the current orthography. Most Koreans with names that historically began with $r$ - still romanize them with $r$ - or $l$ Hence former president No T'aeu is normally romanized as Roh Tae-woo.

10. The phenomenon, which is essentially related to whether a Japanese first encounters an English word through the spoken medium or through the written medium, applies not just to the treatment of $/ \partial /$. Some quite extreme forms may occur, such as the copying of the name Penelope /po'neləpi/ of the character Lady Penelope in the animated TV series Thunderbirds as penerōpu, which would be derived from an English pronunciation /'pentloup/, by analogy with röpu/rəup/ and höpu/həup/.

11. The Japanese forms may be copies from German or another European language, but the Korean forms are clearly copied from Japanese originals. Although an origin from another European language might explain the choice of vowels, it would not explain the use of Korean -yum or other features. For instance, German originals would have been expected to give the Japanese form *katomiumu rather than kadomiumu, which is the source for the Korean copy. 
12. Many underlying word-final and three-consonant word-medial clusters exist, but these are reduced on the surface (Sohn 1994: 441, 476-478). For example, the base form $/ \mathrm{kaps} /$ 'price' is reduced in isolation and before a consonant to $/ \mathrm{kap} /$, and the $/ \mathrm{s} /$ only resurfaces before a vowel-initial suffix, in which case the $/ \mathrm{p} /$ and the $/ \mathrm{s} /$ belong to different syllables.

13. In China and Korea, such bimorphemic compounds are disyllabic, as each Chinese morpheme is one syllable in length. In Japan, assimilation of such morphemes to the strict mora structure of Japanese has resulted in a great many of the morphemes consisting of two morae. Thus, corresponding to Chinese guó, Cantonese gwok, and Korean $k u k$ 'country', Japanese has koku.

14. Truncation is a widely used device in Japanese, applied particularly to Sino-Japanese forms. For example, kokusai rengo 'United Nations' (lit. 'International League') is more commonly referred to in both speech and writing as kokuren, truncating both elements within the compound, and Korean similarly has both kukche (r) yornhap and truncated kunnyon for the same word. Sometimes compounds of native Japanese and Sino-Japanese elements are abbreviated, hence gakusei waribiki 'student discount' is commonly reduced to gakuwari. Even some Western loan-words are doubly truncated, such as $w \bar{a}(d o)$ puro( $\operatorname{sess} \bar{a})$.

15. Autobike is itself not an English formation but falls under the heading of wasei eigo in section 4.3.2.

16. Kuranku and demo are probably not derived directly from English. The short vowel $o$ in demo suggests an original schwa and hence also truncation as the origin. See the comments concerning puro/p'üro. Puropōzu could also be derived from the English verb as puropōzu suru 'to propose' (the suru 'do' is a necessary auxiliary to loan-verbs in order to carry the inflections), and puropōzu 'proposal' is a back-formation from it. Compare with sain 'signature/autograph', which is back-formed from sain suru 'to sign'.

17. As mentioned above, phonemic length tends not to be realized in native Korean words and loan-words into Korean alike, and this is now generally represented in the orthography. Thus, $/ 0: /$ and $/ \partial v /$ merge in Korean as $o$. It must be remembered, however, that this merger is due to changes within the phonology of Korean and not due to borrowing via Japanese. Moreover, two equivalents to Japanese puropōzu exist in Korean. The one, p'úrop'oojü/p'ürop'ojŭ, as listed in Minjungseorim (1972, 1980), is wholly borrowed from Japanese, with the nondiphthongal representation of /ov/ and the reinterpretation of schwa as a stressed vowel based on the spelling of the English. P'ürop'oujü, on the other hand, is the form prescribed by Pak (1988), as well as in Kim's (1977) vocabulary of Korean for Japanese speakers.

18. Japanese does also have the form sutoraiku, which represents the baseball term strike. Sutoraiki, on the other hand, refers to strike in the sense of industrial action.

19. Although it is possible that ero and p'urro have been truncated within Korean rather than having been borrowed in truncated form from Japanese, the latter is the most likely origin. Note that it is the short forms, and not the longer forms, that exist in Korean, suggesting that the words were borrowed short.

20. Korean represents English /mən/ consistently as maen, as in saellorimaen and seiljŭmaen, because each element in an English compound word is treated independently when copied into Korean.

21. The English will only drop the $-s$ in composition: hence pyjama-case, although *pyjama does not occur as an independent form.

22. Sŏngŭrasŭ is a hybrid in Shibatani's sense (see note 1 above). The sŏn is directly from English, the gŭrasŭ directly from Japanese. 
23. Kageyama (1982: 235) points out that coordinative combinations without intervening particles can occur even at the phrasal level: e.g. inu, saru, kiji 'a dog, a monkey, and a pheasant'.

24. An earlier, pronunciation-based version in Japanese produced the Korean form $k^{\prime} a m p ' a s u \check{~ a s ~ r e c o r d e d ~ b y ~ U n d e r w o o d ~ a n d ~ U n d e r w o o d ~(1925) . ~ B o t h ~ t h e ~ K o r e a n ~ a n d ~}$ Japanese forms are now obsolete. It is worth noting that the transcription principles established by the Chosonno Hakhoe during the Japanese occupation (1940b: 9) prescribe $a$ for English $/ \Lambda /$, rather than the $\check{o}$ that has become standard since liberation.

\section{References}

Chosŏnŏ Hakhoe (1940a). Hangŭl Matchumbŏp T'opiran [Proposals for Unifying Hangŭl Orthography]. Seoul: Chosonno Hakhoe.

-(1940b). Oeraeŏ P'yogibŏp T'oniran [Proposals for Unifying the Representation of LoanWords]. Seoul: Chosǒnǒ Hakhoe.

Cousland, Philip B. (1908). An English-Chinese Lexicon of Medical Terms Compiled for the Terminology Committee. Shanghai: Medical Missionary Association of China.

Crowley, Terry (1992). An Introduction to Historical Linguistics, 2nd ed. Auckland, etc.: Oxford University Press.

Eccardt, Thomas; and Oh Wonchul (1993), Hippocrene Handy Dictionaries: Korean. New York: Hippocrene.

Haarmann, Harald (1986). Verbal strategies in Japanese fashion magazines - a study in impersonal bilingualism and ethnosymbolism. International Journal of the Sociology of Language 58, 107-121.

Hannas, William Carl (1994). The Simplification of Chinese Character-Based Writing. Ann Arbor: University Microfilms International.

Hinds, John V. (1974). Make mine burakku. Ǒhak Yðngu 10, 92-108.

Honna, Nobuyuki (1995). English in Japanese society: language within language. Journal of Multilingual and Multicultural Development 16: Multilingual Japan, 45-62.

Kageyama, Taro (1982). Word formation in Japanese. Lingua 57, 215-258.

Kim, Ch'ung-shik (1977). Kankokugo Bunrui Tangoshū [Korean Classified Vocabulary]. Tokyo: Daigaku Shorin.

Kim, Jin-p'yŏng (1983). The letterforms of han'gül: its origin and process of transformation. In The Korean Language, UNESCO (ed.), 80-102. Seoul and Oregon: Si-sa-yong-o-sa and Pace International Research.

Kim, Talgo (1988). Parŭn Malp'yŏnnam [Manual of Correct Language]. Seoul: Kyðng'un Ch'ulp'ansa.

Kokuritsu Kokugo Kenkyūjo (1990). Gairaigo no Keisei to sono Kyõiku [The Formation of Loan-Words and the Teaching of Them]. Tokyo: Kokuritsu Kokugo Kenkyüjo.

Lee, Hansol Hyun-bok (1989). Korean Grammar. Oxford: Oxford University Press.

Lew, Hyungki J. (1949). New Life English-Korean Dictionary. Seoul: New Life Press.

Liu, Yongquan (1986). Terminological development and organization in China. International Journal of the Sociology of Language 59, 33-46.

Lovins, Julie B. (1975). Loanwords and the Phonological Structure of Japanese. Bloomington: Indiana University Linguistics Club.

Lukoff, Fred (1982). An Introductory Course in Korean. Seoul: Yonsei University Press.

Martin, Samuel E. (1992). A Reference Grammar of Korean: A Complete Guide to the Grammar and History of the Korean Language. Rutland, VT, and Tokyo: Tuttle. 
-; and Lee, Young-Sook C. (1969). Beginning Korean. New Haven and London: Yale University Press.

McCawley, James D. (1968). The Phonological Component of a Grammar of Japanese. The Hague and Paris: Mouton.

Mackerras, Colin (1992). Eastern Asia: An Introductory History. Melbourne: Longman Cheshire.

Miller, Roy Andrew (1967). The Japanese Language. Chicago and London: University of Chicago Press.

Minjungseorim (1972). Essence Korean-English Dictionary. Seoul: Minjungseorim.

-(1980). Essence English-Korean Dictionary, 2nd ed. Seoul: Minjungseorim.

Pak, Kapch'ŏn (1988). Sae Hangŭl Match'umbŏp Sajŏn [New Dictionary of Hangŭl Orthography]. Seoul: Chiphyŏnjŏn.

Pak, Kapsu (1984). Kugö-ŭi P'yonyoon-gwa Sunhwa [Expression and Purification of the Korean Language]. Seoul: Chihaksa.

Park, Jeong-Woon (1994). Variation of vowel length in Korean. In Theoretical Issues in Korean Linguistics, Young-Key Kim-Renaud (ed.), 175-187. Stanford: Leland Stanford Junior University CSLI Publications.

Quackenbush, Hiroko C. (1977). English loanwords in Japanese: why are they difficult for English-speaking students? Journal of the Association of Teachers of Japanese 12, 149-173.

Shibatani, Masayoshi (1990). The Languages of Japan. Cambridge: Cambridge University Press.

Sohn, Ho-Min (1994). Korean. London and New York: Routledge.

Tanaka, Katsuhiko; and Lee, Yeonsuk (1986). Aspekte der japanisch-koreanischen Sprachkontakte und Lehnbeziehungen [Aspects of Japanese-Korean language contact and borrowing]. International Journal of the Sociology of Language 58, 123-128.

Twine, Nanette (1991). Language and the Modern State: The Reform of Written Japanese. London and New York: Routledge.

Underwood, Horace Grant; and Underwood, Horace Horton (1925). An English-Korean Dictionary. Seoul: YMCA Printing Department.

Vance, Timothy J. (1986). An Introduction to Japanese Phonology. Albany: State University of New York Press.

Vandesande, Anthony V. (1968). Myŏngdo's Korean. Seoul: Myŏngdo Institute. 